\title{
Evaluation toolkit
}

for educational institutions

Increasing Impact on Senior learners' Quality of Life

\section{Pilar Escuder-Mollón, Salvador Cabedo (coord.)}

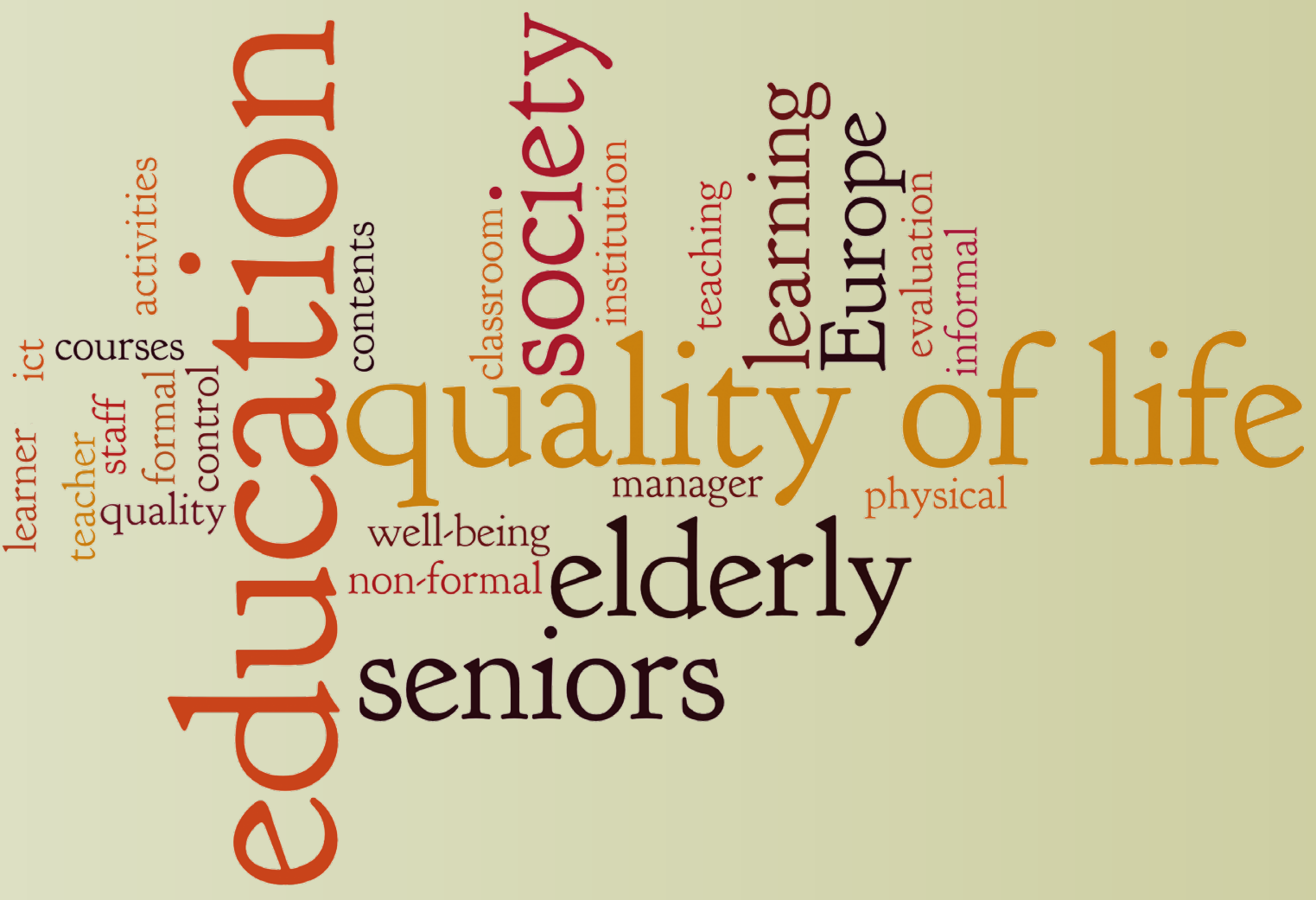




\section{Evaluation toolkit for educational institutions}

Increasing impact on Senior learners' Quality of Life

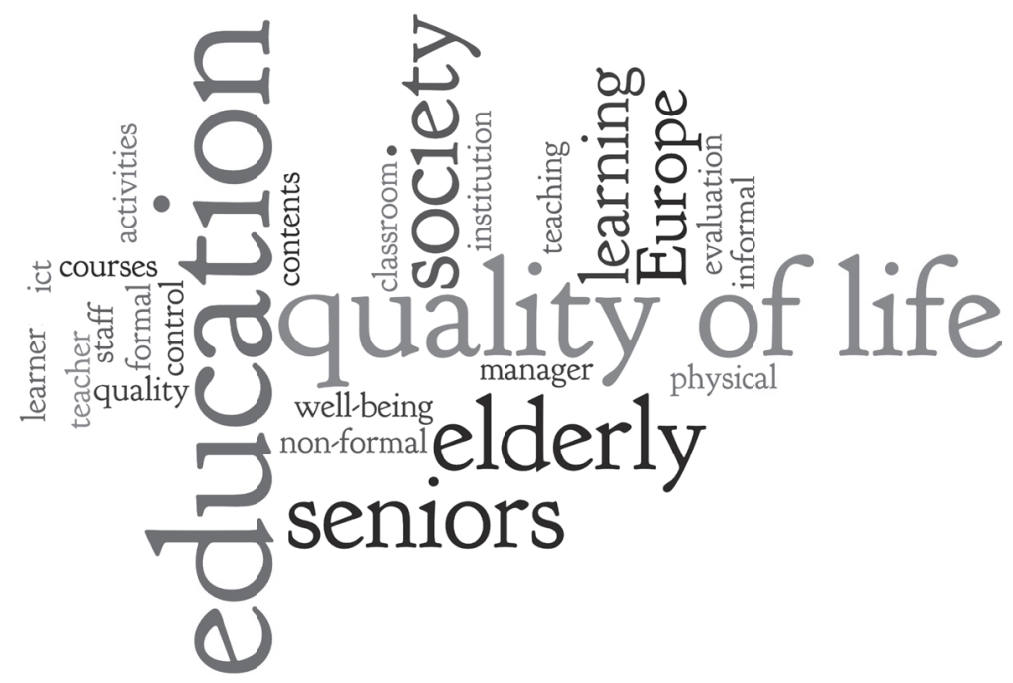

Pilar Escuder-Mollón, Salvador Cabedo (coordinator)
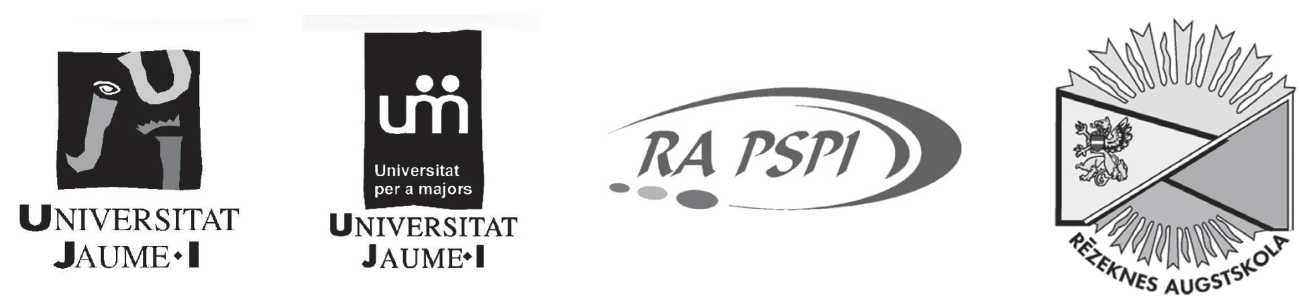
Evaluation toolkit for educational institutions : increasing impact on senior learners' quality of life / Pilar Escuder-Mollon, Salvador Cabedo (coordinador) — Castelló de la Plana : Publicacions de la Universitat Jaume I, D.L. 2014 p.; $\mathrm{cm}$.

Bibliografia.

ISBN 978-84-697-0101-0 (UJI). ISBN 978-9984-44-136-8 (Letònia) 1. Persones grans - Educació -- Avaluació I. Escuder Mollón, Pilar, coord. II. Cabedo Manuel, Salvador, coord. III. Universitat Jaume I. Publicacions $374.7-053.9$

JFSP31

$4 \mathrm{GE}$

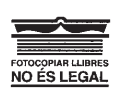

No part of this publication, including the cover design, may be reproduced, stored or distributed in any form or by any means (electronic, chemical, mechanical, optical, print or photocopy) without prior permission from the publisher.

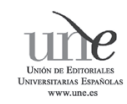

Publicacions de la Universitat Jaume I is a member of the UNE (Union of Spanish University Publishers), which guarantees the distribution and commercialisation of published works nationally and internationally. www.une.es

\section{Published by}

- Publicacions de la Universitat Jaume I. Servei de Comunicació i Publicacions.

Campus del Riu Sec. Edifici Rectorat i Serveis Centrals. 12071 Castelló de la Plana

www.tenda.uji.es e-mail: publicacions@uji.es Fax: 964728232

- Rēzeknes Augstskola. Atbrīvošanas aleja 90, Rēzekne, Latvia

Cover illustration: http://www.wordle.net

ISBN (Spain): 978-84-697-0101-0

ISBN (Latvia): 978-9984-44-136-8

DOI: http://dx.doi.org/10.6035/EvaluationToolkit.2014

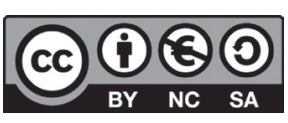

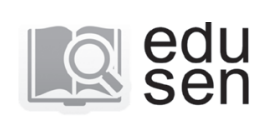

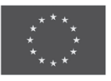

Lifelong

Learning

Programme
This evaluation guide is part of the "Evaluation toolkit on seniors' education to improve their quality of life" project (http://www.edusenior.eu). This project is supported by the Lifelong Learning Programme of the European Commission reference: 518227-LLP-1-2011-1-ES-GRUNDTVIG-GMP.

This project has been funded with support from the European Commission. This communication reflects the views only of the author, and the Commission cannot be held responsible for any use which may be made of the information contained therein. 


\section{TABLE OF CONTENTS}

\section{CONTRIBUTORS}

\section{INTRODUCTION}

\subsection{Context}

1.2. The need for evaluation

1.3. Evaluation toolkit

1.4. The QEduSen Project

\section{EVALUATION PROCESS}

2.1. Motivation

2.2. Target

2.3. The evaluator

2.4. Quality indicators

2.5. Methodology

3. INDICATORS

3.1. Institution

3.2. Management

3.3. Models

3.4. Pedagogy

3.5. Courses

3.6. Activities

3.7. Staff and trainers

\section{ANNEX I}

ANNEX II 


\section{CONTRIBUtORS (ALPHABETICAL ORDER)}

Bardus, Massimo. Università delle LiberEtà, Italy

Bódi, Zsuzsanna. TREBAG Property and Project management Ltd., Hungary

Eloniemi-Sulkava, Ulla. University of Helsinki, Palmenia Centre for Continuing Education, Finland

Escuder-Mollón, Pilar. Universitat Jaume I, Spain

Esteller-Curto, Roger. Universitat Jaume I, Spain

Gil, Alina. Jan Dlugosz University in Czestochowa, Poland

Issakainen, Cecil. University of Helsinki, Palmenia Centre for Continuing

Education, Finland

Kaupuzs, Aivars. Personality Socialization Research Institute of Rezekne Higher Education Institute, Latvia

Lozanova, Slavina. Assist Net, Bulgaria

Lubkina, Velta. Personality Socialization Research Institute of Rezekne Higher Education Institute, Latvia

Nagy, Enikő. TREBAG Property and Projectmanagement Ltd., Hungary

Nowacka, Urszula. Jan Dlugosz University in Czestochowa, Poland

Ochoa Siguencia, Luis. Jan Dlugosz University in Czestochowa, Poland

Raso, Giuseppina. Università delle LiberEtà, Italy

Savtchev, Boian. Assist Net, Bulgaria

Usca, Svetlana. Personality Socialization Research Institute of Rezekne Higher

Education Institute, Latvia 


\section{INTRODUCTION}

\subsection{CONTEXT}

Everybody has the right to continue learning throughout their lives, from cradle to grave. However, children, adolescents, adults and senior citizens have different needs, motivation and requirements for learning; while adults are motivated to continue learning mainly because they need to advance at work or to cope with changes and competitiveness, the motivations of senior citizens (over 65 or retired) are mainly personal: to keep up to date, to be integrated in an ever-changing society, to know more about the environment, or because they want to be active and creative while sharing time and spaces doing an activity they enjoy.

Depending on their targets and objectives, each educational institution designs its educational interventions accordingly (competences, pedagogies, contents, materials, etc.). Our target are senior citizens, and our objective is to increase senior learners' quality of life (QoL).

Three dimensions come together in this scenario: senior citizens' requirements, the design of the educational intervention, and the final aim, to increase QoL. QoL has several dimensions and facets, and also has objective and subjective aspects, some of which can be improved through education, while others can not. In addition, some facets are more important because of seniors' needs and potentialities. An analysis carried out as part of the QEduSen project identified the following QoL characteristics: physical and psychological well-being, perceived control, social integration, participation, personal fulfilment and personal growth. Educational competences were extracted in a second stage analysis ${ }^{1}$. Based on this information, it was possible to define the characteristics an educational institution should have to enable senior learners to achieve these competences.

This evaluation toolkit does not aim to evaluate the learner's competences or knowledge. Nor does it attempt to evaluate the learner's QoL, for which many

1. The research carried out to determine these characteristics is available on the project website: http://www. edusenior.eu. 
evaluation tools are available. The aim of this toolkit is to evaluate the educational institution, in other words, how it organises and delivers its courses and activities ${ }^{2}$.

\subsection{THE NEED FOR EVALUATION}

There is no doubt that the general public commonly associates "evaluation" with a negative and stressful experience; it is understood as something that is applied to assess our work or uncover our weaknesses. Disagreement with the scale or standard that the evaluation applies is also common, leading to the impression that the evaluation results cannot be at all useful. This negative perception of any evaluation procedure needs to change. Evaluation tools offer an excellent opportunity to know more about what we usually do in our institutions from other people's perspectives, and that opportunity should not be ignored. The critical perspective an evaluation tool provides is also positive because it is the staring point to promote change that can then lead to continuous development and improved quality.

An evaluation tool is also based on standards, general context and aims. In the case of this evaluation tool, the context and aims have previously been defined in the first chapters of the Guide. This evaluation tool has not, therefore, been designed to address your institution or your aims, but rather, the impact on senior learners' quality of life.

The role of an evaluator in the methodology we propose is crucial, as he/she is the person that will make the assessment of the institution. This was the main aim of the evaluation tool: to be used as an accreditation tool, to help at the decisionmaking level or to ascertain the degree of achievement or effectiveness in regard to the aims of a positive impact on the learners' quality of life. This evaluation tool was also designed for internal assessment, but also as a learning tool to obtain more information about how education can impact seniors' quality of life. In the next section we explain some other applications of this evaluation tool.

\subsection{EVALUATION TOOLKIT}

This evaluation toolkit is accompanied by a guide, "Education and quality of life of senior learners", and the two publications should be understood as an

2. See chapter 1 "Quality of Life" in the guide "Education and quality of life of senior learners". 
indivisible package. Both products, but especially this evaluation toolkit, have been designed for application in educational institutions whose main aim is not to teach senior citizens to meet professional or job training requirements, but to fulfil their personal motivations.

The guide offers an introduction to the concepts of QoL, seniors' requirements and education potentialities, and provides examples and good practices. If you have no experience in teaching seniors, or your institution is just starting up courses for seniors, then the first step should be to read the guide before proceeding with this toolkit. In any event, it is helpful to read the guide first as it will familiarise you with some of the terms and topics referred to in the toolkit.

The evaluation toolkit provides a methodology, a set of indicators and also an assessment procedure to help you to evaluate the quality of your institution, recognise its weaknesses and improve it in terms of its impact on seniors' QoL. This set of quality indicators can be used in two ways, either internally by staff members, or by external evaluators; in other words, as a way to self-evaluation, to gather ideas and suggestions, or as a way to provide accreditation.

The indicators are designed not only for assessment, but also to help you understand which educational characteristics are important, and to offer some advice. They can be used to show the weaknesses and potentialities of an educational institution, thereby helping managers, technical staff and trainers to increase the quality and impact of their institution.

Finally, the evaluation toolkit can be used by third-parties (such as decision makers, associations, SMEs) to help them identify whether an institution is implementing a teaching-learning activity in the most appropriate way.

\subsection{THE QEDuSen PROJECT}

This guide is part of the results of the QEduSen project "Evaluation toolkit on seniors' education to improve their quality of life". It was supported by the Lifelong Learning Programme of the European Commission, reference 518227-LLP-1-20111-ES-GRUNDTVIG-GMP, from October 2011 to January 2014.

You can find more information about this project in http://www.edusenior.eu and about the LifeLong Learning Programme of the European Commission at http://ec.europa.eu/education/lifelong-learning-programme. 


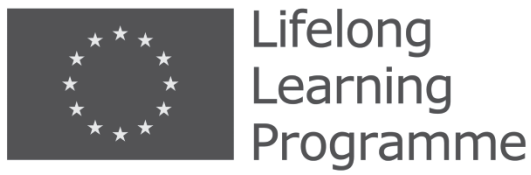

This project has been funded with support from the European Commission. This communication reflects the views only of the authors, and the Commission cannot be held responsible for any use which may be made of the information contained therein. 


\section{EVALUATION PROCESS}

\subsection{MOTIVATION}

This evaluation toolkit is designed to evaluate an educational institution that teaches senior learners (over 65 or retired) whose main motivation to continue learning is personal, not job related. In this context, the evaluation is carried out from the perspective of the impact that the educational intervention has on the learners' Quality of Life.

This evaluation toolkit does not measure learners' QoL. Many other tools and questionnaires are available for that purpose, (see chapter 1 of the guide).

The aim of this toolkit is to evaluate your institution. That is clearly a very ambitious objective which is not easily accomplished, and we recognise the limitations. There are many different kinds of educational institutions with highly contrasting objectives; each institution's target group can also be very different (elderly in good health, elderly immigrants, or elderly at risk, etc.); and the institution's social context and its limitations can also make a big difference. These factors mean that an exhaustive, strict and objective evaluation is impossible. However, we have taken these limitations into account in designing this toolkit as a powerful tool not centred on evaluation to obtain an award where a high score is the most important objective, but rather to be applied in an institution together with the guide and as highly practical tool to find out how to increase the quality of your institution.

You can apply this toolkit:

- to find out your institution's weaknesses and obtain information about how to increase the impact of the educational action on your senior learners' QoL (Figure 1);

- to obtain internal or external accreditation (Figure 2);

- to find out which educational characteristics (courses, activities, etc.) are most suitable to impact facets of QoL (Figure 3). 


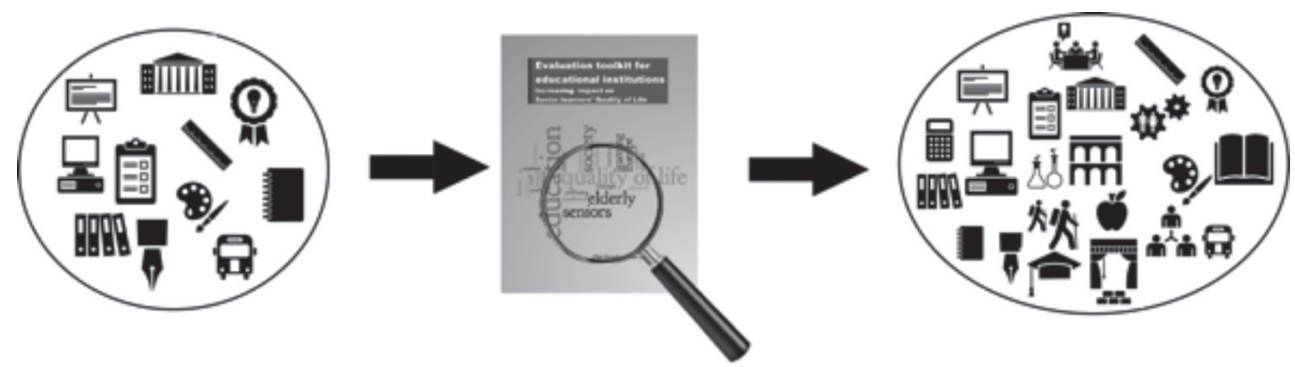

Figure 1. You can use the evaluation toolkit to find an institution's weaknesses and potentialities and raise its quality
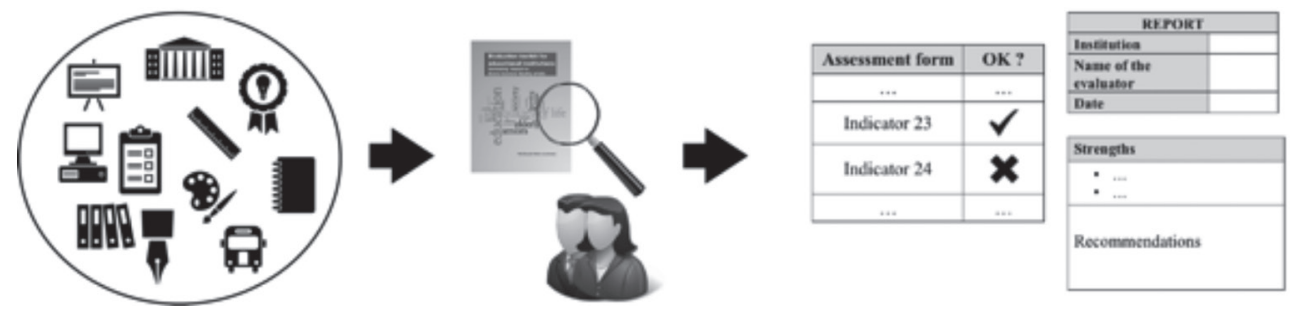

Figure 2. The toolkit can be used for accreditation by external evaluators and for advice and recommendations about how to improve the quality of your institution
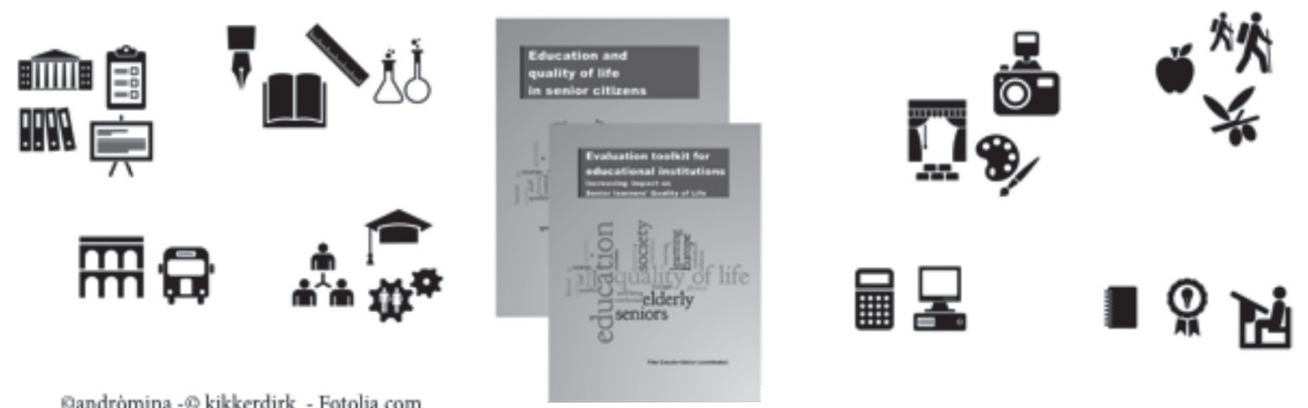

Đandròmina - kikkerdirk - Fotolia.com

Figure 3. The toolkit can be used to learn the most suitable educational characteristics that can impact seniors' quality of life 
Following the evaluation phase, this toolkit has also proven to be very useful:

- as a check-list for doing a study visit to an institution. Indicators are helpful since they provide a checklist of the institution's characteristics so no aspects are missed;

- to receive suggestions and ideas if you want to design and set up an educational programme for seniors;

- at an operational level, to find out in detail the most suitable actions and activities to impact seniors' QoL. The guide "Education and quality of life in senior learners" introduces the basic concepts, but it is in this evaluation toolkit where the theoretical concepts are proposed in a very practical way. The toolkit uses the guide as a reference to find the theoretical background, experiences, context, etc. This is a two-way relationship: readers of the guide can use the toolkit as another source of examples.

\subsection{TARGET}

This evaluation toolkit is designed to target the educational intervention of an institution that encompasses (Figure 4):

- Personnel: managers, technicians, staff, teachers

- Processes, methodologies and organisation of the institution

- Materials, activities, courses and pedagogies applied

- The results and impact: senior learners' subjective perception of the lectures and activities they attend

This evaluation toolkit is not designed to:

- Evaluate senior learners' QoL

- Evaluate senior learners' competences and skills

- Evaluate an educational institution on any criteria other than impact on QoL

Only internal processes in the institution are evaluated, but information can be obtained from several sources to find out about the institution's effectiveness and quality. One of these sources is what the institution does (Educational intervention 
in Figure 5), and another, how it impacts (Feedback in Figure 5). So even though the senior learners are not the target of this evaluation toolkit, their feedback is one very important source of information for the evaluation of the institution.

\subsection{THE EVALUATOR}

This toolkit can be used in two ways (Figure 6):

a. As a list for self-evaluation: managers, technicians or teachers who want to know whether they are working in the right way to increase their learners' QoL, or who are curious to find out what options are available, can refer to the indicators and recommendations.

b. As an external evaluation. In this case, a person outside the institution, with experience in seniors' education, should apply the evaluation methodology to provide a final score and recommendations.

In the first case (self-evaluation) there is no strict methodology to apply this evaluation toolkit. As we assume that you are already very familiar with your institution, you can go straight to the indicators, and focus on the justifications for the indicator and the recommendations.

In the second case, the steps and process described in the next section should be followed and applied. Only in this second case do we refer to a person carrying out the role of evaluator per se.

The evaluator must have following competences:

- basic knowledge of QoL concepts, seniors'needs, pedagogies and educational activities. All these concepts are described in the guide;

- proven experience in adult education;

- experience in evaluation processes: gathering information, proceeding with interviews, reporting;

- familiarity with all indicators in this evaluation tool and also the evidence they require; an understanding of the relationship between the dimension and the justification for each indicator. 


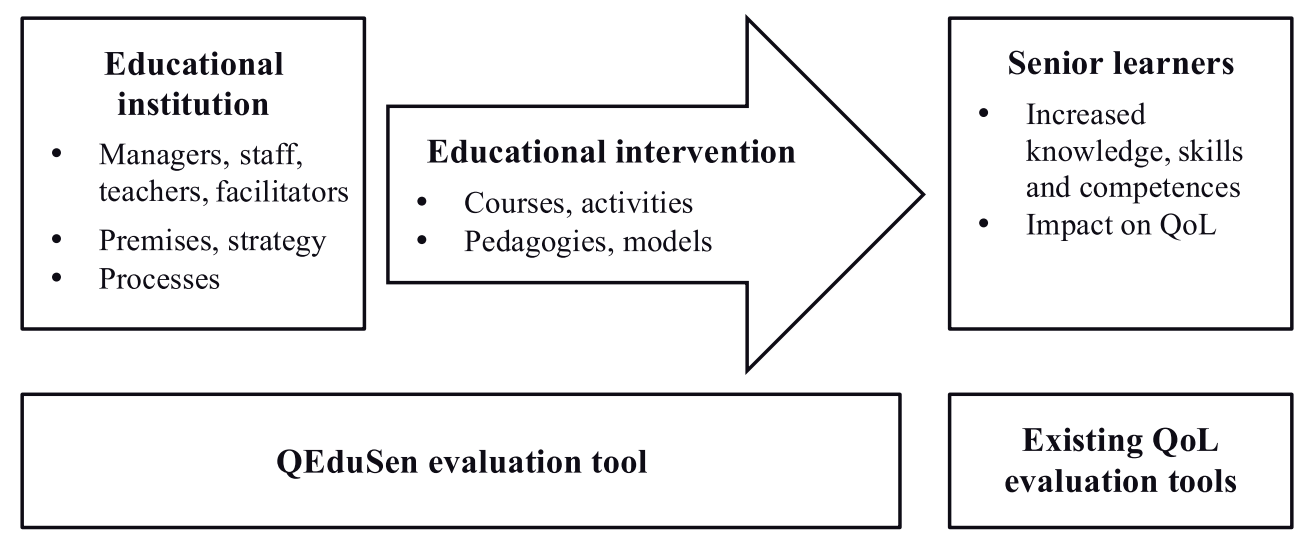

Figure 4. The toolkit aims to evaluate the educational institution and its processes, not the QoL itself

Educational institution

- Managers, staff, teachers, facilitator

- Premises, strategy

- Processes, context, organisation

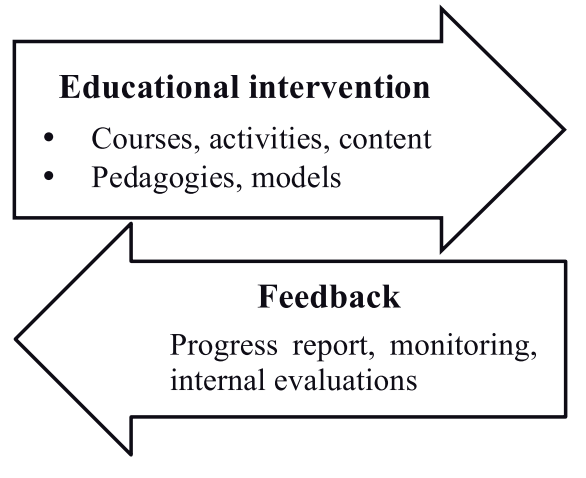

\section{Senior learners}

- Increased knowledge, skills and competences

- Impact on QoL

Figure 5. The intervention and the feedback can be observed to obtain evidence for evaluation 


\section{Internal evaluation (a)}

\begin{tabular}{|c|c|}
\hline Title & Indicator no. 23 \\
\hline Source & - Senior learners \\
\hline Edu. dim. & - Premises \\
\hline QoL dim. & $\begin{array}{l}\text { - Participation } \\
\text { - Personal } \\
\text { fulfilment }\end{array}$ \\
\hline Justification & 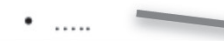 \\
\hline Requirements & $\begin{array}{l}\text { 1. Characteristic } 1 \\
\text { 2. Characteristic } 2 \\
\text { 3. Characteristic } 3\end{array}$ \\
\hline $\begin{array}{l}\text { Recommen- } \\
\text { dations }\end{array}$ & $\begin{array}{l}\text { - Revise .... } \\
\text { - Offer .... }\end{array}$ \\
\hline
\end{tabular}

Toolkit used to:

- know the relationship between institutional dimensions and how they affect quality of life

- gather ideas and recommendations for improvement

\section{External evaluation (b)}

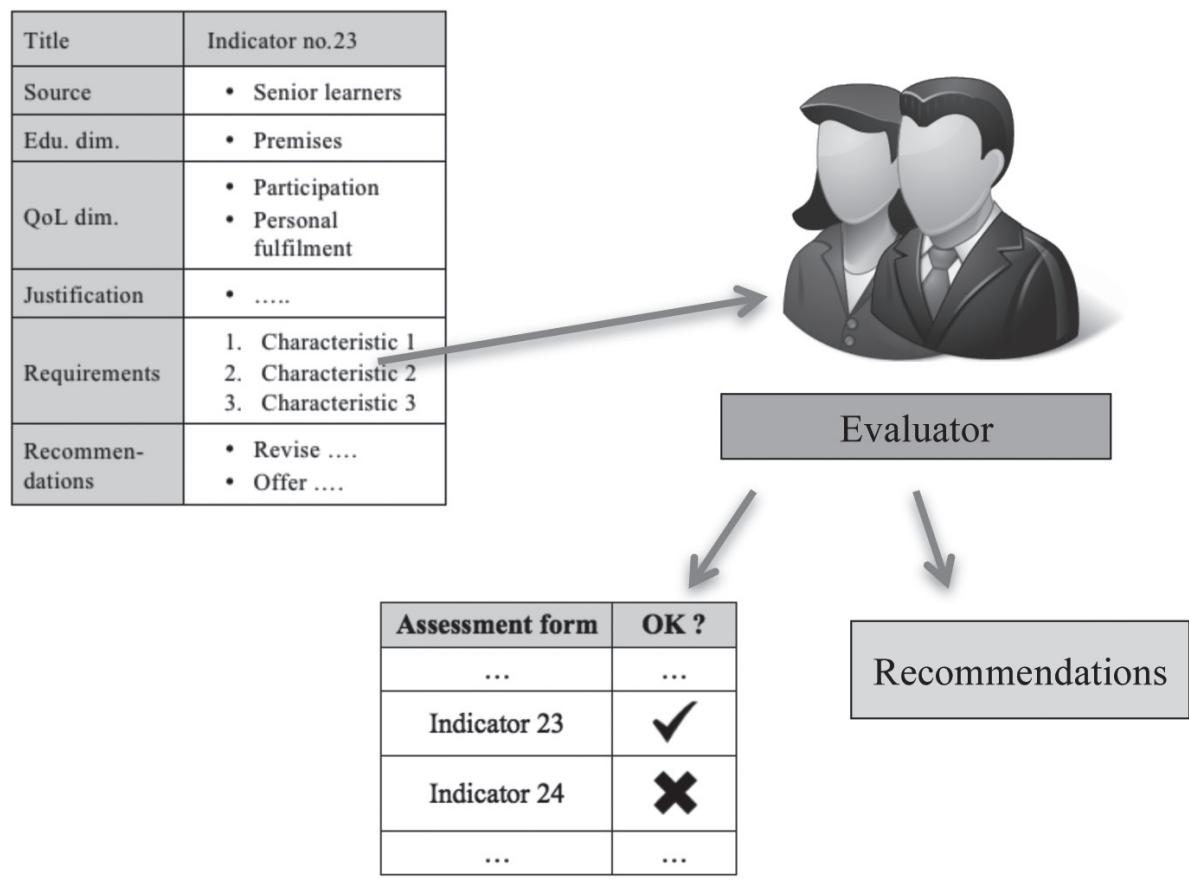

Figure 6. This evaluation methodology can be applied for internal evaluation (a) and external evaluation (b) where indicators are the source of information. In both cases, it aims to arrive at recommendations to improve the quality of the educational institution 


\subsection{QUALITY INDICATORS}

There are 7 educational dimensions and 7 QoL dimensions, on which all indicators have been distributed (Table 2). A study was performed ${ }^{3}$ during the first phase of the project to analyse the QoL dimensions proposed in the most widely recognised theories and works on this topic. From these dimensions, 7 were selected based on the close relation they had with senior citizens' requirements and the potentialities of education. 7 educational dimensions were identified that could differentiate and classify the complexity of any educational programme.

\section{Educational dimensions}

1. Institution: premises (physical buildings) and operational logic (how services are offered and organised).

2. Management and organisation, including:

a. the general aims of the institution (objectives and strategic aims), internal processes of the institution, management decisions and internal regulations.

b. how the work inside the institution is performed, whether regulated, or carried out on the basis of routines and tradition.

3. Educational models: ways the learning contents and activities are delivered. This includes the formal, non-formal and informal models, but educational models are more about:

a. how education is provided by the institution (not how a specific course is offered).

b. the design framework that conditions how it will later be implemented (pedagogies, courses, content, evaluation).

4. Pedagogy: application of techniques and educational methods to courses and activities.

5. Courses: any kind of learning processes where a teacher is involved and has a related teaching plan even if that plan has not been formally established (content, competences to be achieved, pedagogy, timing, objectives, evaluation), example:

3. You can download these research reports from the project website: http://www.edusenior.eu. 
a. practical formal courses, such as ICT and language courses, where learners acquire mainly practical skills.

b. more formal or theoretical courses, such as economics, sociology, philosophy, history, arts, etc. where learners acquire specific knowledge of understanding in those areas.

c. more informal courses, such as cooking, handicrafts, dancing, choir, theatre group etc. (where they have a teaching plan).

6. Activities: any kind of learning process where a teacher is not involved continuously and has no teaching plan, for example:

a. a website, conference or any dissemination activity

b. research or project-related activities

c. trips organised by learners, lunches, dinners, other social events

d. extra-academic activities such as a choir or theatre group (where it is organised as a leisure activity)

7. Staff and trainers: includes the operational level of the personnel -coordinators, teachers, tutors, facilitators, administrative staff, etc.

a. competences and skills;

b. functions and responsibilities.

\section{QoL dimensions}

1. Physical health. Increasing.

a. the health of the individual, reducing pain or illness (requiring less medication or visits to the doctor) or increasing independence;

b. knowledge about the general ageing process, illness or good habits; lowering risks, delaying the impact of ageing or improving selfperception.

2. Psychological health. Increasing.

a. positive attitudes towards the ageing process

b. cognitive and mental functioning

c. protective factors for psychological disorders like depression

3. Integration.

a. feeling integrated in society, with more communicative and social skills

b. improved knowledge of the environment 
4. Participation. Increasing participation.
a. in the educational institution
b. in communities, families, friends
c. in society in general

This participation can be encouraged by creating, sharing or being an active part of a group.

5. Control. Related to increasing perceived control (internal and external, primary and secondary).

a. Improving learners' skills and competences to discuss, negotiate, and communicate, but also to accept and adapt.

b. Acquiring skills to analyse and know more about ourselves and how we are related to the environment (links with other people).

6. Personal growth. Increasing optimism, motivation, energy to do things.

7. Personal fulfilment. Spending time usefully and pleasurably, feeling comfortable, spending time on oneself, fruitful leisure time for oneself.

We found other institutional characteristics that could affect seniors' QoL indirectly. These characteristics are important because they can increase the impact of educational activities, although they do not have a direct link with any of the previous dimensions. These indicators can help raise the quality of the institution's effectiveness in impacting senior learners' QoL, and they can therefore affect all the QoL dimensions. In the table they are referred to as "Indirect transfers".

\section{Indicator structure}

- Each indicator has the following structure.

- Identification number: a sequential number for ease of reference.

- Title: a single descriptive sentence.

- Source: proposed sources for gathering evidence.

- Educational dimension: one or several of the above-mentioned dimensions in which an institution has control and power to act.

- QoL dimension. One or several of the above-mentioned dimensions that can have an impact on the senior learner's QoL.

- Justification: description of the indicator, why it must be considered, what the relationship is between the education and QoL. How the indicator, QoL and the institutional dimension are related. How QoL is increased through that educational action. 
- Proof or evidence: how the evaluator can check that the indicator requirements are met.

- Recommendations: these alert the evaluator to the institution's failure to meet the indicator requirements.

- All indicators are presented in tables (Figure 7) and are available in section 3.

\begin{tabular}{|c|c|}
\hline Title & Indicator no 23 \\
\hline Source & - Senior learners \\
\hline Edu. dim. & - Premises \\
\hline QoL dim. & $\begin{array}{l}\text { - Participation } \\
\text { - Personal } \\
\text { fulfilment }\end{array}$ \\
\hline Justification & - $\ldots .$. \\
\hline Requirements & $\begin{array}{l}\text { 1. Characteristic } 1 \\
\text { 2. Characteristic } 2 \\
\text { 3. Characteristic } 3\end{array}$ \\
\hline $\begin{array}{l}\text { Recommen- } \\
\text { dations }\end{array}$ & $\begin{array}{l}\text { - } \text { Revise .... } \\
\text { - Offer .... }\end{array}$ \\
\hline
\end{tabular}

Figure 7. Individual view of an indicator

\section{METHODOLOGY}

When the evaluation procedure is carried out by an external officer, the evaluation methodology has the following steps:

Preparation:

1. The evaluator becomes familiar with the indicators for evaluation. He or she should also be thoroughly aware of the main principles and ideas explained in the guide. 
Evaluation procedure:

2. Information gathering; the evaluator collects as much information from the institution as possible (Figure 8).

3. Interviews: based on the information collected and the indicators, the evaluator arranges and carries out interviews with staff, trainers and senior learners (Figure 9).

4. Step 2 and 3 can be repeated to clarify any doubts or obtain more detailed information about specific indicators.

5. Assessment: the evaluator completes the final report, namely, the templates of annex I and annex II (Figure 10).

The following sections provide a detailed, step-by-step explanation of this methodology. When the evaluation is done internally it is unnecessary to follow this methodology so strictly, although in this case the evaluation will not be valid for external accreditation, but for other purposes (as explained in the previous section).

\section{Information gathering}

The evaluator will have an initial meeting with the manager of the institution. Only with the manager's willingness and approval will it be possible to gain a first impression of the institution and have access to documentation and the rest of the staff.

Each indicator includes the evidence that must be considered, but before taking the individual indicators into account, a general overview of the institution is necessary; information should be gathered (Figure 8) from the following sources:

- internal rules and regulations, flyers, documents, the website

- list of courses and activities offered, teaching plan, photos, records

- visual observation of the premises

A contact person from the staff (technician, co-ordinator) and a trainers' representative should accompany the evaluator and assist in gathering information. During this phase, the evaluator can also ask the staff and trainer:

- about unwritten regulations or work habits, general organisational rules

- about any doubts concerning the information being gathered 


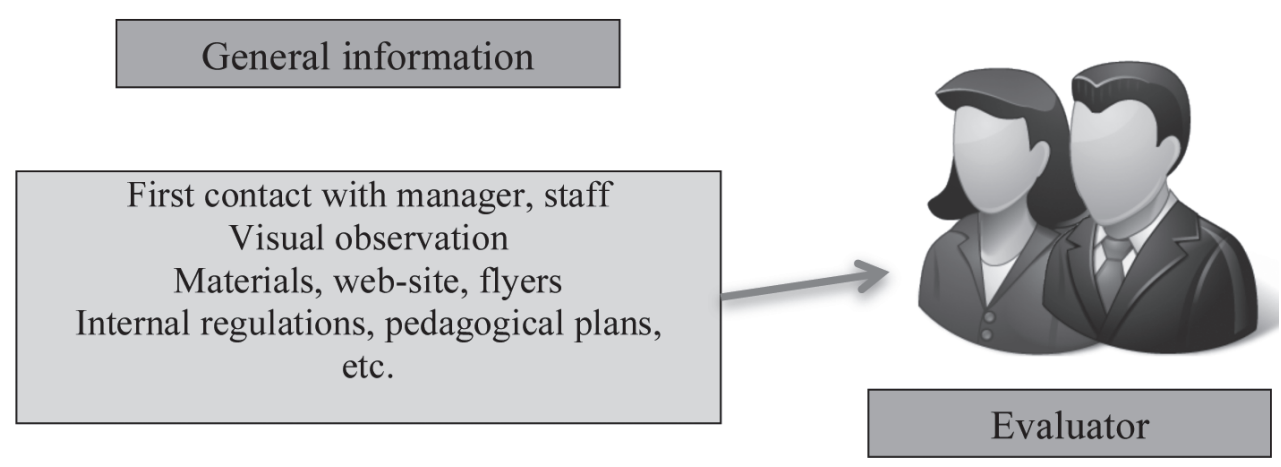

Figure 8. During the initial contact, the evaluator observes and collects relevant information

\section{Interviews}

Once the general information has been gathered (courses, activities, flyers, internal regulation, photos, news-letters, etc.) then the evaluator should read carefully all the indicator requirements (Figure 9) in order to prepare questions for interviews with each of the following individuals or groups:

- manager

- staff, technicians, trainers

- learners

It would be unfeasible to expect to meet all the teachers and learners. Meetings should be arranged with a random sample of the trainers (around $10 \%$ of the trainers, a minimum of 5 ) and learners ( $2 \%$ of the learners, a minimum of 10$)$. All the staff and learners should have at least one academic year's experience in the institution. Only after this meeting should the evaluator extend the meeting phase or contact specific staff, in accordance with his/her own criteria.

All these interviews and any conclusions drawn from other observations should be recorded in a diary (date, hour, time spent, documents obtained, description of the process, customs and routines, etc.). This diary is confidential and must remain in the evaluator's possession. 
Indicator

\begin{tabular}{|c|c|}
\hline Title & Indicator no 23 \\
\hline Source & - Senior learners \\
\hline Edu. dim. & - Premises \\
\hline QoL dim. & $\begin{array}{l}\text { - Participation } \\
\text { - Personal } \\
\text { fulfilment }\end{array}$ \\
\hline Justification & - \\
\hline Requireme & $\begin{array}{l}\text { 1. Characteristic } 1 \\
\text { 2. Characteristic } 2 \\
\text { 3. Characteristic } 3\end{array}$ \\
\hline $\begin{array}{l}\text { Recommen- } \\
\text { dations }\end{array}$ & $\begin{array}{l}\text { Revise } \\
\text { - Offer .... }\end{array}$ \\
\hline
\end{tabular}

\section{Manager, staff, trainers, senior learners}

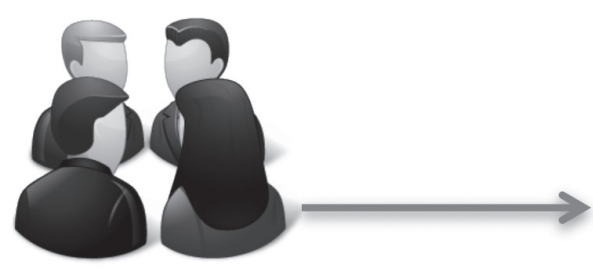

Information collected

Visual observation

Materials, web-site, flyers

Internal regulations, pedagogical plans, etc.
Script, questions, doubts, etc. (preparing the interviews)

Figure 9. Based on the information collected, and the information needed to assess each indicator, the evaluator analyses the institution in greater depth (interviews, visiting classrooms, talking to specific trainers, etc)

\section{Assessment}

The Assessment Grid should be filled in (Annex I) providing a value for each indicator (Figure 10). This is not a psychometric survey, so the scale does not measure whether the evaluator agrees or disagrees with the indicator. An overall performance rating model is used, based on the evidence and proof related to each indicator. In this model, each indicator is given a score based on the level to which the indicator requirements are met. 


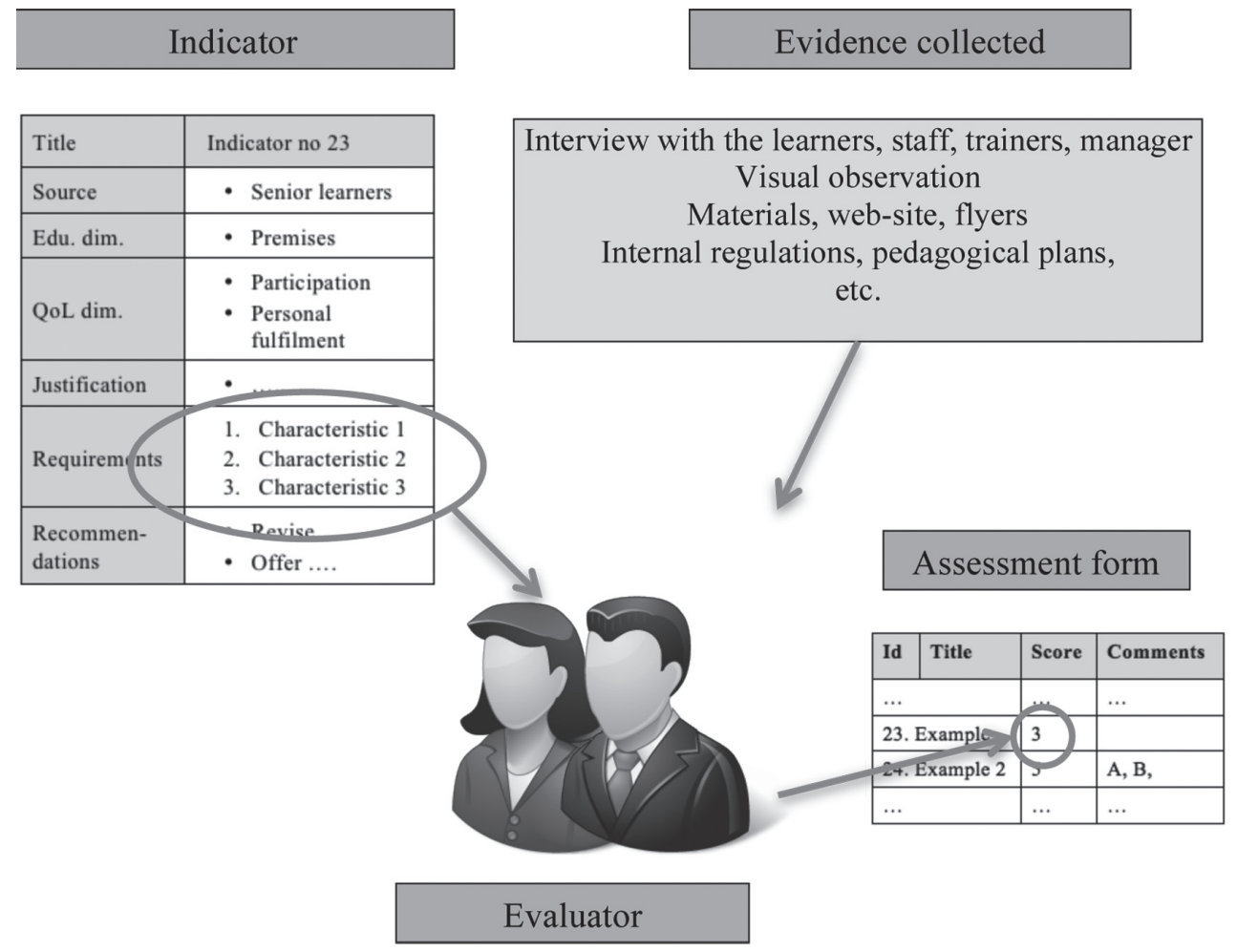

Figure 10. Assesment procedure is carried out based on each indicator's requirements (characteristics, proof needed) and evaluating the extent to which the evidence shows that the institution address those needs.

Each indicator has between 2 and 5 requirements (which are the criteria that have to be met, characteristics of the indicator). The evaluator should consider whether the requirements are adequately met according to the description of the indicator (justification). This process is illustrated in Figure 10.

The score assigned to the indicator will be higher or lower according to the weaknesses or quality aspects. In this assessment grid, the scores run from 0 to 5 , where 3 is the threshold indicating the minimum acceptable level (Table 1). As this is not a scale, but a score, decimals between values can be used. 
TABLE 1. SCORE AND DESCRIPTION FOR THE ASSESMENT OF INDICATORS

\begin{tabular}{|l|l|}
\hline Score & Description \\
\hline $\begin{array}{l}\text { Not applicable } \\
\text { (no score) }\end{array}$ & $\begin{array}{l}\text { The indicator cannot be applied because of the cultural context, } \\
\text { aims of the institution or the target characteristics }\end{array}$ \\
\hline 0 - No evidence & $\begin{array}{l}\text { Fails to include a minimum amount of evidence to enable evalu- } \\
\text { ation of the indicator }\end{array}$ \\
\hline 1 - Very weak & $\begin{array}{l}\text { Meets the indicator's requirements but with significant or many } \\
\text { weaknesses }\end{array}$ \\
\hline 2 - Weak & Meets the indicator's requirements but with some weaknesses \\
\hline 3 - Acceptable & Meets the indicator's requirements satisfactorily (threshold) \\
\hline 4 - Good & Meets the indicator's requirements with some high quality aspects \\
\hline 5 - Very good & Meets the indicator's requirements, all aspects of high quality \\
\hline
\end{tabular}

The threshold level is equal to a score of 3: an indicator receives a score of 3 (Acceptable) when all the requirements (the proof and evidence required) are met, based on the information gathered by the evaluator.

A score of 2 should be given when the institution meets the requirements with some weaknesses, as follows:

a. Evidence failures. Some of the evidence for the requirements is unsatisfactory; requirements are not met.

b. Design failures. The activity or the process is not designed correctly or well-implemented to meet the requirements on which the indicator is based and considering the justification of the indicator.

c. Low impact. Only a small proportion of the learners or staff benefit from the educational action on which the requirement is based.

A score of 1 should be given when a significant number of the abovementioned weaknesses are evident. See Figure 11 for a graphic relation between those factors and the score.

A score of 0 should be given when not enough information is provided to consider that any of the requirements are met.

Scores of 4 and 5 should be given when quality aspects are met; a score of 5 denotes that all quality aspects are met. The quality aspects are any complementary or satellite activities, measures or processes that enable a greater impact on the QoL dimensions on which the indicator is justified. Quality aspects for a specific indicator (based on their proof and evidence) are: 
A. Well-established evidence. The requirements will be met in the long term and not as isolated occurrences (in time, duration or reached by all the learners), because measures are in place to ensure long-term exploitation, all learners in the institution have access, or it is part of a well-defined strategy in the institution.

B. Continuous improvement. There is a quality procedure to detect weaknesses and to improve them through innovation or research, such as regular evaluation procedures, pilot tests, or research groups.

C. Indirect transfer. Based on the justification of the indicator, there is other evidence related to other institutional dimensions (other extra-academic activities, complementary subjects, workshops, etc.) that reinforces and strengthens the skills, attitudes and aptitudes that the senior is learning or acquiring.

D. Exchange. There are proven relations and synergies between external actors that result in a beneficial impact on the elderly in general, on the institution quality and effectiveness, or on the society's image of the elderly (dissemination activities, presentation). These external actors may be other areas or departments in the institution, other institutions (associated institutions, association, networks), in society (other social actors) or participation in projects related to the activities that form part of the indicator or dissemination.

Not only the number of quality aspects or weaknesses should be considered to increase or lower the score, but also the extent to which they are met (Figure 11).

Note that the quality aspects (A, B, C, D) and the weaknesses (a, b, c) detailed above are provided only as suggested factors to modify the score of an indicator as some of them are not applicable in some indicators. Also, the description should be considered as an example of weaknesses or quality aspects. Evaluators can consider more than these if they consider it necessary.

This quantitative measure will provide a final score for the quality of the institution's impact on the QoL of the senior learners. As there are 38 indicators and the maximum score is 5 , a total score of 190 would be 10 out of 10 . The threshold would be a total score of 114; that is 6 out of 10 .

A model of the Assessment Grid is provided on Annex I and on the website http://www.edusenior.eu. 


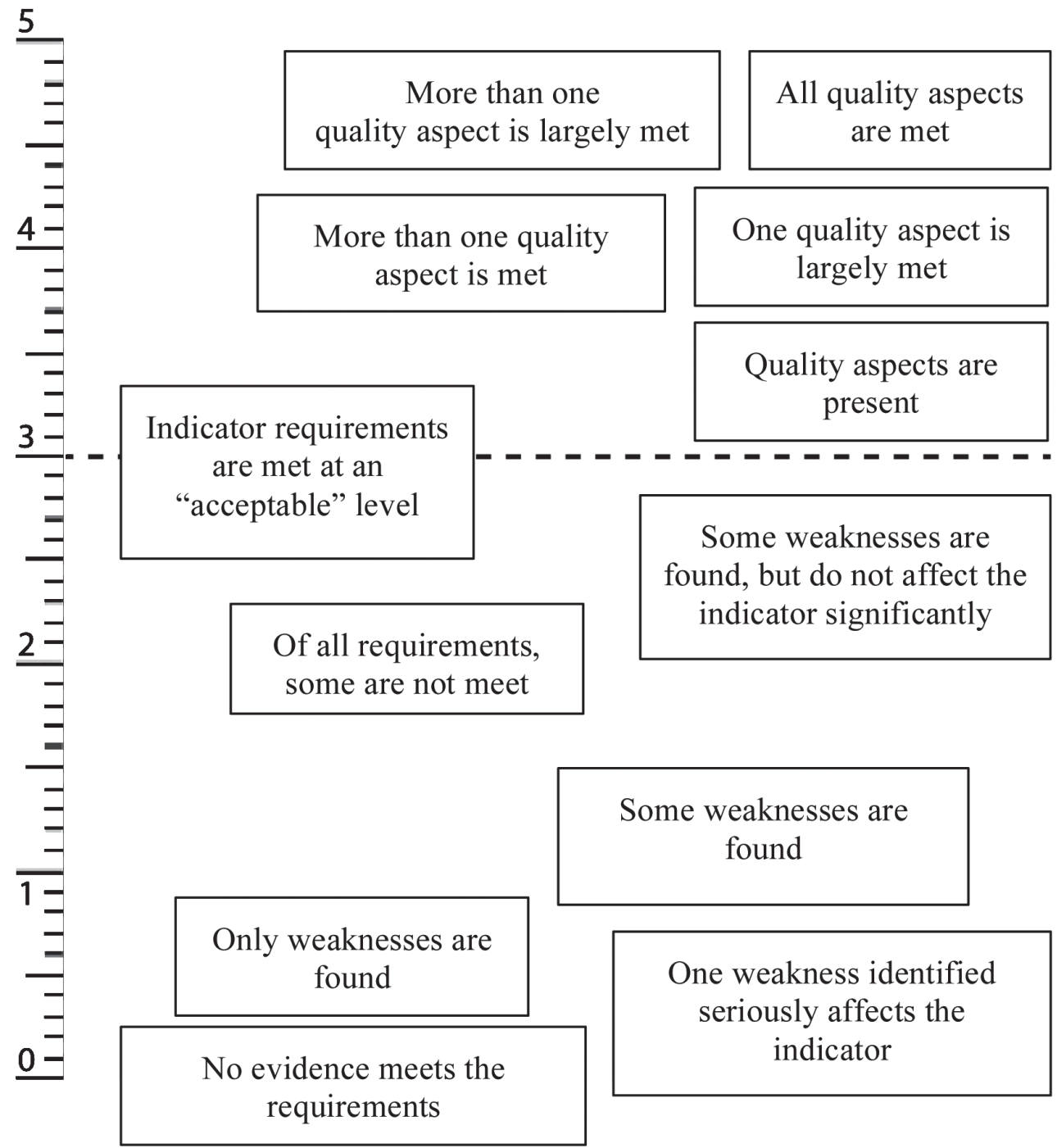

Figure 11. Relation between the score and the quality aspects and weaknesses. 


\section{Information gathering $\left(2^{\text {nd }}\right.$ phase)}

After filling out the questionnaire, it may be necessary to gather further information from the institution to clarify doubts or other aspects of the questionnaire in order to fill the quantitative report (Figure 12).

\section{Assessment form}

\begin{tabular}{|l|l|l|l|}
\hline Id & Title & Score & Comments \\
\hline$\ldots$ & $\ldots$ & $\ldots$ \\
\hline 23. Example & 3 & \\
\hline 24. Example 2 & 5 & A, B, \\
\hline$\ldots$ & $\ldots$ & $\ldots$ \\
\hline
\end{tabular}

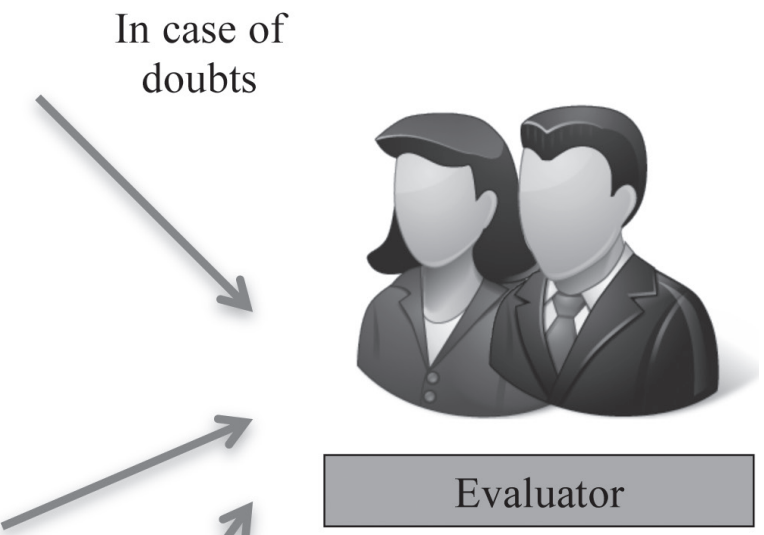

\section{Manager, staff, trainers, senior learners}
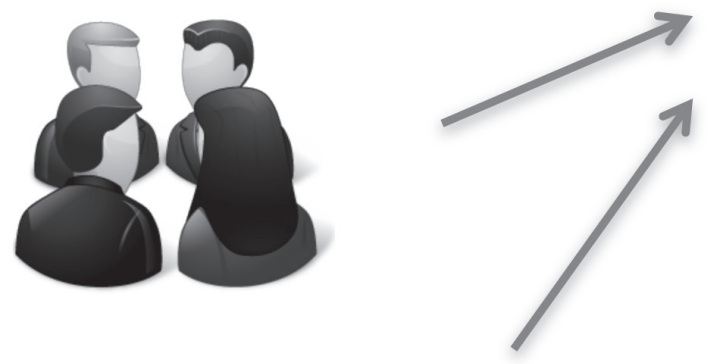

\section{Evaluator}

Collection, gathering extra information

Visual observation

Materials, web-site, flyers

Internal regulations, pedagogical plans, etc.

Figure 12. If there are doubts about the score for some indicators, then requirements and documentation should be revised, specific staff members re-interviewed, etc. 
Evaluation process

\section{Reporting}

Each indicator provides recommendations that are also linked to the Guide contents. The final report aims to correct the evaluation performed in the previous phase, based on the specific aims, target and social context of the institution, by providing advice and recommendations (Figure 13).

A model is provided in Annex II, and on the website http://www.edusenior.eu.

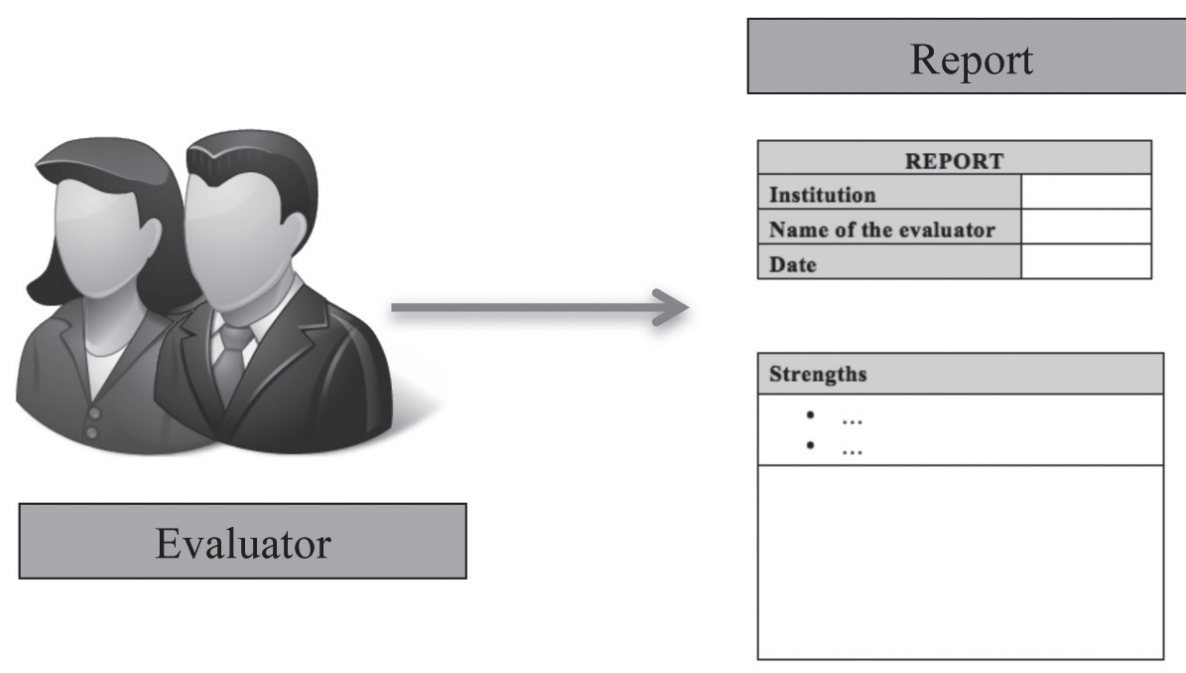

Figure 13. A qualitative report should be filled in based on the assessment results 


\section{INDICATORS}

There are 38 indicators divided into 7 educational dimensions that can belong to any of the 7 QoL dimensions, plus one considered source (indirect transfer). All the indicators have an ID, so it becomes easy to later refer to it in the report. Following are all the indicators:

TABLE 2. RELATIONSHIP OF INDICATORS CLASSIFIED IN EDUCATIONAL AND QoL DIMENSIONS

\begin{tabular}{|c|c|c|c|c|c|c|c|c|c|}
\hline \multirow[b]{2}{*}{ 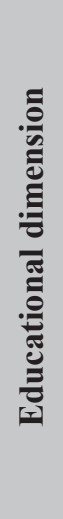 } & \multirow[b]{2}{*}{ Title } & \multicolumn{8}{|c|}{ QoL dimension } \\
\hline & & 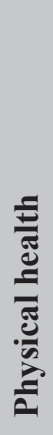 & 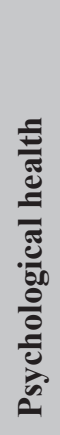 & 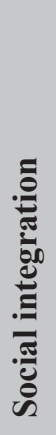 & 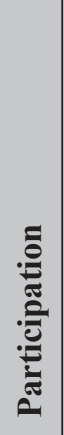 & 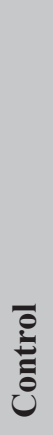 & 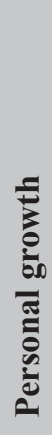 & 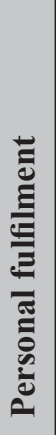 & 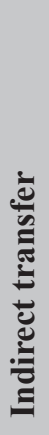 \\
\hline \multirow{3}{*}{ 泀 } & 1. Accessibility & & & & $\checkmark$ & & & $\checkmark$ & \\
\hline & 2. Meeting points & & $\checkmark$ & $\checkmark$ & & & & $\checkmark$ & \\
\hline & 3. Spaces for participation & & & & $\checkmark$ & & & $\checkmark$ & \\
\hline \multirow{4}{*}{$\begin{array}{l}\dot{00} \\
\stackrel{\Xi}{\tilde{\Xi}} \\
\sum\end{array}$} & 4. Institutional self-evaluation & & & & & & & & $\checkmark$ \\
\hline & 5. Social activity promotion & & & & & & $\checkmark$ & $\checkmark$ & \\
\hline & 6. Senior's requirements evaluation & & & & & & & & $\checkmark$ \\
\hline & 7. Participation of learners in management & & & & $\checkmark$ & $\checkmark$ & & & \\
\hline
\end{tabular}




\begin{tabular}{|c|c|c|c|c|c|c|c|c|c|}
\hline \multirow[b]{2}{*}{ 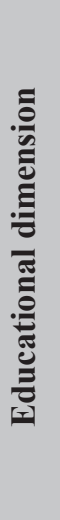 } & \multirow[b]{2}{*}{ Title } & \multicolumn{8}{|c|}{ QoL dimension } \\
\hline & & 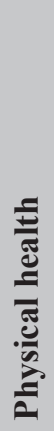 & 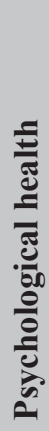 & 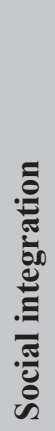 & : & 吕 & 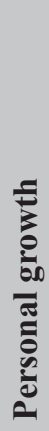 & 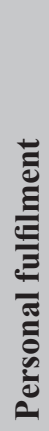 & 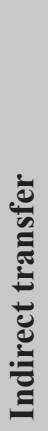 \\
\hline \multirow{7}{*}{$\begin{array}{l}\frac{n}{0} \\
\frac{0}{0} \\
\sum\end{array}$} & 8. Learning provider & & & & $\sqrt{ }$ & & & 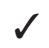 & \\
\hline & 9. Learners' accreditation & & & & & & & $\checkmark$ & \\
\hline & 10. Acquiring social attitudes informally & & $\checkmark$ & $\checkmark$ & & $\checkmark$ & $\checkmark$ & $\checkmark$ & \\
\hline & 11. Formal learning provider & & & & & & & & $\checkmark$ \\
\hline & 12. Formal learning groups & $\checkmark$ & $\checkmark$ & $\checkmark$ & & & $\checkmark$ & & \\
\hline & 13. Comprehensive educational activity & & $\checkmark$ & & & $\checkmark$ & $\checkmark$ & $\checkmark$ & \\
\hline & 14. Intergenerational learning & & $\checkmark$ & $\checkmark$ & & $\checkmark$ & $\checkmark$ & $\checkmark$ & \\
\hline \multirow{4}{*}{ 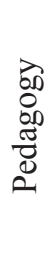 } & 15. Constructive pedagogy & & & & & $\checkmark$ & $\checkmark$ & $\checkmark$ & \\
\hline & 16. Learn by research & & & & $\checkmark$ & $\checkmark$ & $\checkmark$ & $\checkmark$ & \\
\hline & 17. Participatory pedagogy & & & $\checkmark$ & $\checkmark$ & $\checkmark$ & & & \\
\hline & 18. Learn to learn & & & & $\checkmark$ & $\checkmark$ & $\checkmark$ & & \\
\hline \multirow{9}{*}{ 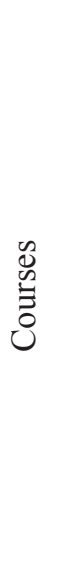 } & 19. Competences for life changes & & & & & $\checkmark$ & $\checkmark$ & $\checkmark$ & \\
\hline & 20. Digital adoption & & & & $\checkmark$ & & $\checkmark$ & $\checkmark$ & \\
\hline & 21. Physical & $\checkmark$ & $\checkmark$ & & & & & & \\
\hline & 22. Languages & & $\checkmark$ & $\checkmark$ & $\checkmark$ & & & & \\
\hline & 23. Problem-based learning & & & $\checkmark$ & & $\checkmark$ & & & \\
\hline & 24. Psychological well-being & & $\checkmark$ & & & $\checkmark$ & $\checkmark$ & $\checkmark$ & \\
\hline & 25. Cultural trips & & & $\checkmark$ & & & & $\checkmark$ & \\
\hline & 26. Informal learning outside the classroom & $\checkmark$ & $\checkmark$ & & & $\checkmark$ & & & \\
\hline & 27. Increase in cognitive skills & & $\checkmark$ & & & & & & \\
\hline
\end{tabular}




\begin{tabular}{|c|c|c|c|c|c|c|c|c|c|}
\hline \multirow[b]{2}{*}{ 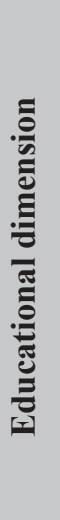 } & \multirow[b]{2}{*}{ Title } & \multicolumn{8}{|c|}{ QoL dimension } \\
\hline & & 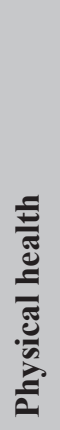 & 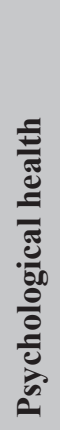 & 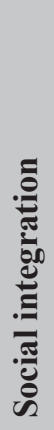 & 童 & ن̈ & 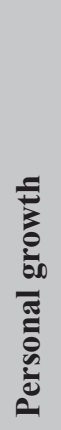 & 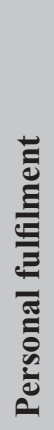 & 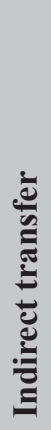 \\
\hline \multirow{6}{*}{ : } & 28. Social meetings & & & $\checkmark$ & & & & $\checkmark$ & \\
\hline & 29. Artistic performances & & & & & & & $\checkmark$ & \\
\hline & 30. Volunteering as a social contribution & & & & $\checkmark$ & & & $\checkmark$ & \\
\hline & 31. Digital inclusion & & & $\checkmark$ & $\checkmark$ & $\checkmark$ & $\checkmark$ & $\checkmark$ & \\
\hline & 32. Expertise exchange & & $\checkmark$ & & & $\checkmark$ & & & \\
\hline & 33. Artistic creativity & & $\checkmark$ & & & & $\checkmark$ & $\checkmark$ & \\
\hline \multirow{5}{*}{ 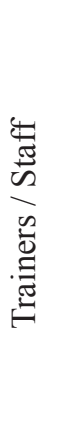 } & 34. Gerontology training & & & & & & & & $\checkmark$ \\
\hline & $\begin{array}{l}\text { 35. Intercultural awareness, diversity and } \\
\text { multiculturalism }\end{array}$ & & & $\checkmark$ & $\checkmark$ & & & & \\
\hline & 36. Trainers' communication skills & & & & & & & & $\checkmark$ \\
\hline & $\begin{array}{l}\text { 37. Professional burnout and stress manage- } \\
\text { ment }\end{array}$ & & & & & & & & $\checkmark$ \\
\hline & 38. Motivation and optimism & & $\checkmark$ & & & $\checkmark$ & $\checkmark$ & $\checkmark$ & \\
\hline
\end{tabular}

NOTE: this table is not necessary for the assessment procedure; it is only provided for your information, to show the relationship between the indicators and the dimensions

\subsection{INSTITUTION}

The dimension of the "institution" includes the premises (physical buildings) and operational logic (how services are offered and organised). 


\begin{tabular}{|c|c|}
\hline Title & 1. Accessibility \\
\hline Source & $\begin{array}{l}\text { - Internal regulation of the institution, management } \\
\text { - Institutional materials (website, flyers...) } \\
\text { - Visual inspection of classrooms and other spaces } \\
\text { - Senior learners }\end{array}$ \\
\hline Edu. dim. & Premises \\
\hline QoL dim. & $\begin{array}{l}\text { Participation } \\
\text { - Personal fulfilment }\end{array}$ \\
\hline Justification & $\begin{array}{l}\text { Accessibility is a key issue in the provision of education for seniors and } \\
\text { a pre-requisite for making it a success. } \\
\text { Seniors must be made to feel comfortable, and disabled people must also } \\
\text { be motivated to learn. The environment is therefore a facilitator for social } \\
\text { participation, and motivational factor in the enjoyment of learning. } \\
\text { Premises, furniture and equipment should be as user-friendly as } \\
\text { possible for seniors, disabled users or those with special needs related } \\
\text { to the specifics of their ageing process. Issues not commonly taken into } \\
\text { consideration, or seen as 'minor', such as facilities for the disabled or } \\
\text { people with decreased mobility, impaired vision or hearing loss, should } \\
\text { also be addressed. } \\
\text { This involves ensuring easy access and special equipment and facilities. }\end{array}$ \\
\hline Requirements & $\begin{array}{l}\text { 1. The fonts, colours and general design of the materials printed, presented } \\
\text { or displayed are access-friendly (e.g., non-confusing colours for colour- } \\
\text { blind users, clear, large fonts, icons). } \\
\text { 2. The classrooms and the communal areas in the institution (offices, } \\
\text { library, cafeteria, toilets) are accessible for disabled people. The furniture } \\
\text { is placed correctly in terms of layout, use of space, height of equipment, } \\
\text { width of passageways, lighting, heating, ventilation, use of colour. } \\
\text { 3. There institution has a plan on how to address the needs of the elderly } \\
\text { (hearing difficulties, impaired vision, colour-blindness) that can be } \\
\text { applied whenever any senior learner requires it using human or material } \\
\text { resources. }\end{array}$ \\
\hline 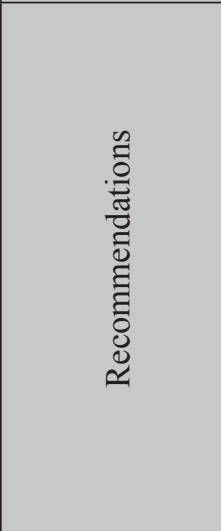 & $\begin{array}{l}\text { Update any written information taking into account the appropriate } \\
\text { accessibility rules (on website, flyers, posters, etc). } \\
\text { Make all appropriate instructions and training on how to use equipment } \\
\text { available to staff and users. } \\
\text { Make sure appropriate facilities and equipment are in place for seniors } \\
\text { with special needs and disabled users. } \\
\text { Seek advice from professionals on how to deal with the specific needs of } \\
\text { senior learners. } \\
\text { Define the 'level of accessibility' (e.g., wheelchair access, availability of } \\
\text { induction loops) for users with special needs/disabled users. } \\
\text { Consider offering users some of the current facilities and services at a } \\
\text { distance (by phone, post, Internet). }\end{array}$ \\
\hline
\end{tabular}




\begin{tabular}{|c|c|}
\hline Title & 2. Meeting points \\
\hline Source & $\begin{array}{l}\cdot \text { Visual verification } \\
\cdot \text { Management } \\
\cdot \text { Senior learners } \\
\end{array}$ \\
\hline Edu. dim. & - Premises \\
\hline QoL dim. & $\begin{array}{l}\text { Personal fulfilment } \\
\text { - Social integration } \\
\text { - Psychological health }\end{array}$ \\
\hline Justification & $\begin{array}{l}\text { Seniors attend courses not only for their educational value, but } \\
\text { also to integrate in the social context of their community. It is } \\
\text { important, therefore, to have some communal spaces other than } \\
\text { the classrooms where they can spend time chatting, relaxing or } \\
\text { reading a book before or after the lessons. } \\
\text { - These places can be used to turn 'non-useful' time (e.g., between } \\
\text { classes) into productive time: meeting classmates, acquiring com- } \\
\text { munication and social skills and learning before/after a class. } \\
\text { They also provide a comfortable space for those who are not used } \\
\text { to meeting new people; they can begin making contacts in a place } \\
\text { where they do not feel awkward or threatened. }\end{array}$ \\
\hline Requirements & $\begin{array}{l}\text { 1. Learners have a communal place to use before or after the classes } \\
\text { in the institution. } \\
\text { 2. Learners feel comfortable and relaxed in the place. } \\
\text { 3. Coffee or other beverages and magazines or books are available. }\end{array}$ \\
\hline 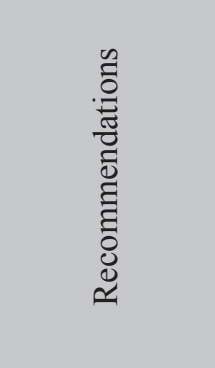 & $\begin{array}{l}\text { Provide a communal space with simple furniture where learners } \\
\text { can spend time sitting and chatting or reading while having some- } \\
\text { thing to drink. } \\
\text { - Provide an area with a small library where they can choose books } \\
\text { and magazines to read, or exchange books. } \\
\text { - Put up a notice board in this space for official announcements } \\
\text { from the institution or informal messages from learners; if pos- } \\
\text { sible, provide computers for free access. }\end{array}$ \\
\hline
\end{tabular}




\begin{tabular}{|c|c|}
\hline Title & 3. Spaces for participation \\
\hline Source & $\begin{array}{l}\text { Physical and virtual spaces (such as websites) } \\
\text { - Management } \\
\text {. Senior learners }\end{array}$ \\
\hline Edu. dim. & Premises \\
\hline QoL dim. & $\begin{array}{l}\text { Participation } \\
\text { Personal fulfilment }\end{array}$ \\
\hline Justification & $\begin{array}{l}\text { Learners have to see the educational institution as something more } \\
\text { than a place for learning: as a platform where they can express them- } \\
\text { selves, participate and be creative. } \\
\text { The institution must provide resources, tools and methods to create } \\
\text { the opportunity for this increased participation, in the institution and } \\
\text { in the community. } \\
\text { Whether or not there are already activities designed to encourage } \\
\text { creativity, this type of space should be created and facilitated to open } \\
\text { up opportunities for senior learners; writing in a magazine, writing } \\
\text { stories or experiences in a forum, taking photos and preparing exhi- } \\
\text { bitions, etc. } \\
\text { The institution should have a way of showing and disseminating } \\
\text { seniors' original creations. This has an impact on the creators (self- } \\
\text { esteem, increased motivation and enjoyment) and the other learners } \\
\text { and society. }\end{array}$ \\
\hline Requirements & $\begin{array}{l}\text { 1. There is a communication platform (virtual or real) where learners } \\
\text { can participate and express themselves on a regular basis (e.g., mag- } \\
\text { azine, radio, social network forum on the organisation's website). } \\
\text { 2. Work done in other activities is disseminated (e.g., photographic or } \\
\text { handicraft exhibitions). } \\
\text { 3. Learners have the means to organise amongst themselves and do ac- } \\
\text { tivities together (e.g., meeting rooms, notice boards, mail-lists, etc.). }\end{array}$ \\
\hline 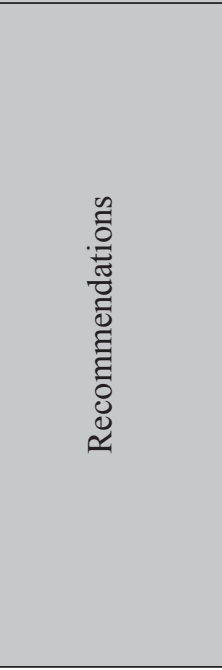 & $\begin{array}{l}\text { Create a small magazine or web platform where learners can explain } \\
\text { or ask about anything they are interested in. They can talk about } \\
\text { their experiences on the last trip, local history, stories, etc. Make this } \\
\text { publication available to the wider community. } \\
\text { Encourage learners to join in and organise activities, providing the } \\
\text { tools and means to anybody interested in suggesting or organising } \\
\text { an activity. A notice board can be useful, as can an on-line forum } \\
\text { or virtual social network, to encourage learners to create links and } \\
\text { organise amongst themselves. } \\
\text { If a course or activity has a creative element (poetry, English com- } \\
\text { positions, photography, handicrafts, etc), it is highly motivational if } \\
\text { learners can show their results somewhere in the institution. } \\
\text { Initiatives for participation will also help to create a sense of be- } \\
\text { longing to the institution. These could include a photography com- } \\
\text { petition, competition to design logos for t-shirts or a logo for the } \\
\text { website, etc. }\end{array}$ \\
\hline
\end{tabular}




\subsection{MANAGEMENT}

The dimension of management and organisation includes:

- the general aims of the institution (objectives and strategic aims), internal processes of the institution, management decisions and internal regulations;

- how the work inside the institution is performed, whether regulated or carried out on the basis of routines and tradition.

\begin{tabular}{|c|c|}
\hline Title & 4. Institutional self-evaluation \\
\hline Source & $\begin{array}{l}\text { Internal regulation, reports on evaluations already performed and } \\
\text { planned } \\
\text { Management } \\
\text { Trainers } \\
\text { Senior learners }\end{array}$ \\
\hline Edu. dim. & Management \\
\hline QoL dim. & Indirect transfer \\
\hline $\begin{array}{l}\text { Justifica- } \\
\text { tion }\end{array}$ & $\begin{array}{l}\text { As well as the external evaluations conducted by outside bodies, there } \\
\text { is a well-defined need for institutional internal or self-evaluation of the } \\
\text { senior education programmes and courses, to make sure the services, } \\
\text { courses and activities are meeting standards and senior learners' expec- } \\
\text { tations and needs. The institutional internal or self-evaluation is the most } \\
\text { effective way to gather feedback and introduce changes for improve- } \\
\text { ment in due course. } \\
\text { These evaluations should ask learners to indicate their levels of satisfac- } \\
\text { tion with the contents, trainers, or activities. } \\
\text { In the surveys or questionnaires, learners can also be invited to make } \\
\text { suggestions or proposals for new activities. This is a good way of obtain- } \\
\text { ing feedback about seniors' needs. }\end{array}$ \\
\hline $\begin{array}{l}\text { Require- } \\
\text { ments }\end{array}$ & $\begin{array}{l}\text { 1. There is a procedure for internal evaluation of the courses, activities and } \\
\text { trainers, carried out annually, based on the aims of the institution and the } \\
\text { quality of the educational action. } \\
\text { 2. The trainers, specialists and learners (as end-users) are part of the evalu- } \\
\text { ation process. } \\
\text { 3. The results of the internal evaluation are used to identify } \\
\text { good practices and areas where corrective actions are needed. } \\
\text { Actions are taken when necessary. }\end{array}$ \\
\hline
\end{tabular}




\begin{tabular}{|c|c|}
\hline Title & 4. Institutional self-evaluation \\
\hline 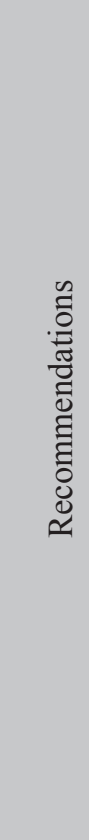 & $\begin{array}{l}\text { Provide for well-planned evaluation (e.g., at the beginning and the end } \\
\text { of the academic year). } \\
\text { Assess services, programmes, courses and activities for both efficiency } \\
\text { and effectiveness. } \\
\text { Make senior learners an active and integral part of the evaluation pro- } \\
\text { cess, in order to } \\
\text { · assess their satisfaction, } \\
\text { - learn whether the educational goals and aims are met, } \\
\text { - learn whether the services, programmes, courses and activities reflect } \\
\text { senior learners' needs. } \\
\text { Make sure the staff takes part in all stages of the evaluation: from the } \\
\text { design, through the implementation, to the processing of the results and } \\
\text { the decisions for improvement. } \\
\text { Make decisions for improvement based on actual evaluation results and } \\
\text { not on any subjective perceptions. } \\
\text { Measure changes and impact on learners. } \\
\text { Identify and introduce good practices. } \\
\text { Implement a system of continuous evaluation and improvement by com- } \\
\text { paring educational performance over time. }\end{array}$ \\
\hline
\end{tabular}

\begin{tabular}{|c|c|}
\hline Title & 5. Social activity promotion \\
\hline Source & $\begin{array}{l}\cdot \text { Staff } \\
\cdot \text { Senior learners }\end{array}$ \\
\hline Edu. dim. & $\begin{array}{l}\text { Management } \\
\text { Activities }\end{array}$ \\
\hline QoL dim. & $\begin{array}{l}\text { - Personal growth } \\
\text { - Personal fulfilment }\end{array}$ \\
\hline Justification & $\begin{array}{l}\text { Besides educational activities, the institution can usefully encourage } \\
\text { students to group and organise activities by themselves. These activities } \\
\text { are not intended to be used for learning, and should not be organised by } \\
\text { the staff of the institution, but institutional support is important. } \\
\text { This kind of activity can be inside the institution (e.g., birthday celebra- } \\
\text { tions, volunteer activity to help other learners), but it is usually outside } \\
\text { (dinners, trips, events such as opera, theatre, etc). } \\
\text { Support for these activities at an institutional level facilitates their or- } \\
\text { ganisation and the inclusion of other learners. It allows learners who } \\
\text { do not usually have the chance, or who feel reluctant to go alone, to } \\
\text { attend events or participate in activities they would not otherwise do; it } \\
\text { increases their chances of sharing leisure time with other students and } \\
\text { making new contacts. }\end{array}$ \\
\hline
\end{tabular}




\begin{tabular}{|c|c|}
\hline Title & 5. Social activity promotion \\
\hline $\begin{array}{l}\text { R e quire - } \\
\text { ments }\end{array}$ & $\begin{array}{l}\text { 1. The institution promotes social activities outside the institution by pro- } \\
\text { viding the means for socialisation (like meeting rooms) and communica- } \\
\text { tion (like newsletters) that learners can use to organise themselves. } \\
\text { 2. Social activities are organised by the learners in which the staff play a } \\
\text { secondary role; staff are not directly involved but facilitate the organisa- } \\
\text { tion and provide advice or support when necessary. } \\
\text { 3. Information is available (flyers, newsletters, etc) about activities suitable for } \\
\text { the elderly (e.g., theatre, opera, cinema, trips, hiking and walking, gyms). }\end{array}$ \\
\hline 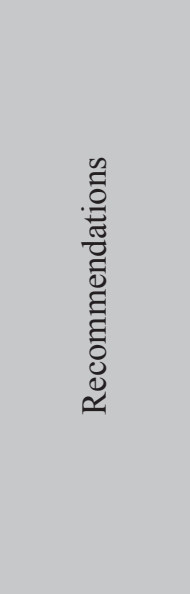 & $\begin{array}{l}\text { Senior learners can organise any kind of activity on their own, but exter- } \\
\text { nal activities (dinner, excursions, trips, etc.) should be supported by the } \\
\text { institution. This support allows the institution to guide the activity so it } \\
\text { is done in a useful and productive way, perhaps helping to avoid harmful } \\
\text { or less advisable activities. } \\
\text { - If the activity involves organising a group to go together to the opera, } \\
\text { theatre, cinema, etc., then the organisation can try to get a group price. } \\
\text { - If the activity is supported by the educational institution, senior learners } \\
\text { who are less integrated or shy may feel more comfortable about joining } \\
\text { in. The institution should, firstly, not discourage the activity, and sec- } \\
\text { ondly, provide some organisational resources such as use of classrooms } \\
\text { for organisation purposes, use of notice boards for communication. } \\
\text { - Provide a notice board and a table for flyers and leaflets, or a newsletter } \\
\text { about cultural activities in the area. }\end{array}$ \\
\hline
\end{tabular}

\begin{tabular}{|c|c|}
\hline Title & 6. Seniors' requirements evaluation \\
\hline Source & $\begin{array}{l}\text { Reports on previous and planned evaluations } \\
\text { Manager, staff } \\
\text { Senior learners }\end{array}$ \\
\hline Edu. dim. & Management \\
\hline QoL dim. & Indirect transfer \\
\hline Justification & $\begin{array}{l}\text { Before designing an educational intervention to increase senior learners' } \\
\text { quality of life it is useful to know what their specific needs and require- } \\
\text { ments are. } \\
\text {. An evaluation to find out senior citizens' educational preferences (the } \\
\text { subjects they enjoy most) is not enough. It is necessary to know in } \\
\text { which aspects of QoL they have lower values: physical health, psycho- } \\
\text { logical well-being, communication, support, productivity, etc. }\end{array}$ \\
\hline 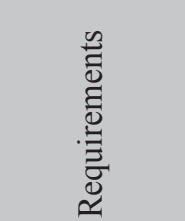 & $\begin{array}{l}\text { 1. There is a process (interview, evaluation) that reveals new learners' re- } \\
\text { quirements and risks that could lower their quality of life. } \\
\text { 2. There is a process to monitor learners' evolution. This process may be } \\
\text { formal (records or formal interviews) or informal (where tutors or facili- } \\
\text { tators monitor the learner's progress). }\end{array}$ \\
\hline
\end{tabular}




\begin{tabular}{|l|l|}
\hline & $\begin{array}{l}\text { Introduce short questionnaires about perceptions of quality of life and } \\
\text { needs and distribute the aggregated results among all the trainers and staff. } \\
\text { This will also make them aware of where their activities should have an } \\
\text { impact. } \\
\text { - The questionnaires used may be from the World Health Organisation, the } \\
\text { Cummings questionnaire or the one used during the analysis phase of the } \\
\text { QEduSen project, available at http://www.edusenior.eu }\end{array}$ \\
A facilitator or tutor should also make contact with the learners (before or \\
after the classes) to gain a thorough knowledge of their interests, motiva- \\
tions, problems, etc. \\
A senior learner's main aim is not to acquire a lot of knowledge and com- \\
petences leading to a formal qualification; their life experience, present \\
context and future expectations make a big difference to their perception \\
of QoL. If these requirements are common to most of the learners, the \\
educational activity must be designed accordingly. If the requirements \\
are individual, some support or brief contact with the facilitator or tutor \\
may be enough to have a major impact on the senior learner.
\end{tabular}

\begin{tabular}{|c|c|}
\hline Title & 7. Participation of learners in management \\
\hline Source & $\begin{array}{l}\text { Internal regulation, minutes of last board meeting } \\
\text {. Management } \\
\text {. Senior learners }\end{array}$ \\
\hline Edu. dim. & Management \\
\hline QoL dim. & $\begin{array}{l}\text { Participation } \\
\text { - Control }\end{array}$ \\
\hline Justification & $\begin{array}{l}\text { Senior learners should feel and know that they are not mere spectators of } \\
\text { the education they are receiving; they are the main actors and they should } \\
\text { participate actively in the process. They should learn to participate and } \\
\text { provide feedback. } \\
\text { Compared with other kinds of education focused more on competitiveness } \\
\text { and job skills, seniors' education is mostly driven by the learners' personal } \\
\text { motivations. Learners should feel that the institution also belongs to them } \\
\text { through some kind of participation in the decision-making process. } \\
\text { Participation should be oriented to receive feedback from the learners, and } \\
\text { take corrective actions in any educational aspect to better meet their aims. }\end{array}$ \\
\hline 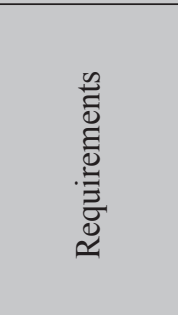 & $\begin{array}{l}\text { 1. There are senior learners' representatives whose functions are to liaise } \\
\text { with the management or staff on behalf of all the learners. The learners can } \\
\text { formally constitute a board of representatives. } \\
\text { 2. There is a formal procedure in which the representatives can meet with the } \\
\text { management or provide feedback. } \\
\text { 3. The suggestions, questions and inquiries from the senior representatives } \\
\text { are considered (solved, or when not solved, at least justified). }\end{array}$ \\
\hline
\end{tabular}




\begin{tabular}{|l|l|}
\hline Title & 7. Participation of learners in management \\
\hline & $\begin{array}{l}\text { Senior learners should have a channel to voice their concerns, suggestions } \\
\text { and improvements for the educational activity they attend, thereby partici- } \\
\text { pating in the institution and feeling that they are part of it. }\end{array}$ \\
$\begin{array}{l}\text {. } \\
\text { Senior learners should have a channel in which to participate in the insti- } \\
\text { tutional process, which should also be understood as way of participating } \\
\text { in external processes or in activities that affect them. Institutions should } \\
\text { promote this participation, but seniors should also learn to accept the co- } \\
\text { ordinator's decisions. }\end{array}$ \\
\hline
\end{tabular}

\subsection{MODELS}

The educational models refer to the ways the learning contents and activities are delivered. This includes the formal, non-formal and informal models, but educational models are more concerned with:

- how education is provided by the institution (not how a specific course is offered);

- the design framework that conditions how it will later be implemented (pedagogies, courses, content, evaluation).

\begin{tabular}{|c|c|}
\hline Title & 8. Learning provider \\
\hline Source & Management \\
\hline Edu. dim. & Models \\
\hline QoL dim. & Indirect transfer \\
\hline $\begin{array}{l}\text { Justifica- } \\
\text { tion }\end{array}$ & $\begin{array}{l}\text { The design of courses and activities must be based on seniors' general needs } \\
\text { and QoL requirements. } \\
\text { The courses and activities must also match the aims of the institution and at- } \\
\text { tempt to achieve the long-term strategies of the institution. } \\
\text { Details of the subjects must be available to all the learners, providing not only } \\
\text { the title, but also a justification of the content. Learners must understand why } \\
\text { subjects are included in the course programme. In this way, the subject is pre- } \\
\text { sented as attractive, motivational and also perceived as useful (for a specific } \\
\text { competence or need). }\end{array}$ \\
\hline
\end{tabular}




\begin{tabular}{|c|c|}
\hline Title & 8. Learning provider \\
\hline $\begin{array}{l}\text { Require- } \\
\text { ments }\end{array}$ & $\begin{array}{l}\text { 1. All the subjects are listed and available to all senior learners with enough time } \\
\text { and sufficient information (description, timing, trainer) for them to make in- } \\
\text { formed choices. } \\
\text { 2. All the subjects have a teaching plan that describes at least the objectives, con- } \\
\text { tent and timing. Trainers provide sufficient information about how the plan is } \\
\text { developed (pedagogy, evaluation, materials). } \\
\text { 3. The set of subjects offered each year is based on a criterion properly defined by } \\
\text { a board of experts, a gerontologist or other specialised team members. All the } \\
\text { subjects are consciously designed following a strategic plan (based on institu- } \\
\text { tional aims and matching the QoL dimensions). }\end{array}$ \\
\hline 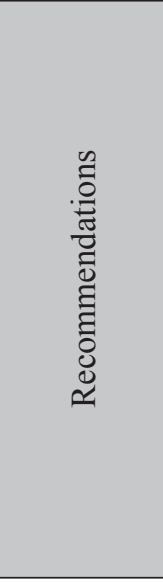 & $\begin{array}{l}\text { There should be an interdisciplinary board of experts to decide which subjects } \\
\text { and courses are offered. That decision must be grounded (aims of the institu- } \\
\text { tion, seniors citizens' needs, legal requirements, etc), but it must also state how } \\
\text { the courses will be provided (other technical staff or trainers can then detail the } \\
\text { teaching plan). } \\
\text { - The information about the courses and subjects offered should have enough } \\
\text { detail for learners to make an informed choice about which ones to enrol on. If } \\
\text { these are mandatory subjects, reasons justifying why this is the case should be } \\
\text { given to learners. } \\
\text { Senior learners usually register on courses because they like the subject or think } \\
\text { it is interesting. However, specifying the competences and skills they will ac- } \\
\text { quire from the course will encourage learners to consider not only whether they } \\
\text { like the subject topic, but also whether it makes a useful contribution to their } \\
\text { life-skills. }\end{array}$ \\
\hline
\end{tabular}

\begin{tabular}{|c|c|}
\hline Title & 9. Learners' accreditation \\
\hline Source & . Management \\
\hline Edu. dim. & Models \\
\hline QoL dim. & - Personal fulfilment \\
\hline 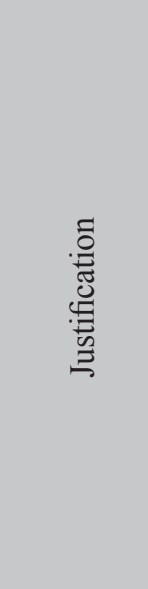 & $\begin{array}{l}\text { Although senior learning does not fall within the formal model because it is } \\
\text { not strictly regulated by government, it is advisable for learners to be awarded } \\
\text { certificates or diplomas for the studies they complete. } \\
\text { - Senior learners can see a diploma (or certificate or achievement) as a goal to } \\
\text { aim for, and they may be motivated to take more subjects and competences if } \\
\text { their efforts are recognised. Subjectively it is a reward for their efforts (internal } \\
\text { validation) and praise from colleagues, friends and family (external validation). } \\
\text { - Providing a certificate or diploma is a way of raising the level of formality of the } \\
\text { education; the courses are not regarded as leisure activities or simply a pleasant } \\
\text { way of passing the time. } \\
\text { Formalising education not only means that the subjects must be offered and } \\
\text { designed appropriately; it also implies that a method of evaluation must be in } \\
\text { place. Learners have to make some effort to pass the subject, otherwise it would } \\
\text { seem that learning is simply a passive activity. }\end{array}$ \\
\hline
\end{tabular}




\begin{tabular}{|c|c|}
\hline Title & 9. Learners' accreditation \\
\hline $\begin{array}{l}\text { Require- } \\
\text { ments }\end{array}$ & $\begin{array}{l}\text { 1. There is a method to evaluate learners. This method must not be too strict, as it } \\
\text { could have a negative impact (anxiety, stress). } \\
\text { 2. Learners receive some accreditation for the competences acquired in the form } \\
\text { of certificates or diplomas. }\end{array}$ \\
\hline 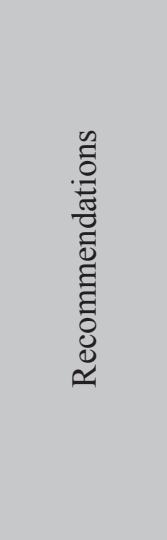 & $\begin{array}{l}\text { There must be some kind of evaluation or assessment where only the } \\
\text { learners that meet the requirements obtain the diploma. The evaluation } \\
\text { must not be too strict or difficult, but based on attendance, coursework, or } \\
\text { an easy, simple exam. If not, it could lead to stress or anxiety. } \\
\text { - This evaluation ensures that the learner understands that passing a subject } \\
\text { or a course requires some effort, learning is not a passive activity and they } \\
\text { are partly responsible for the teaching-learning process. } \\
\text { Obtaining a certificate or diploma creates the perception of achievement } \\
\text { for themselves and for their classmates, friends and family. It gives a tar- } \\
\text { get to aim for and recognises the effort involved in learning. } \\
\text { A diploma or certificate increases self-esteem and raises the positive per- } \\
\text { ception of the learner in the eyes of his or her relatives and friends. Impact } \\
\text { is increased if an awards ceremony is organised to present the diplomas. }\end{array}$ \\
\hline
\end{tabular}

\begin{tabular}{|c|c|}
\hline Title & 10. Acquiring social attitudes informally \\
\hline Source & $\begin{array}{ll}\cdot & \text { Trainers } \\
\cdot & \text { Senior learners }\end{array}$ \\
\hline Edu. dim. & · Models \\
\hline QoL dim. & $\begin{array}{ll}\cdot & \text { Social integration } \\
\cdot & \text { Control } \\
\cdot & \text { Personal growth } \\
\cdot & \text { Personal fulfilment } \\
\cdot & \text { Psychological health } \\
\end{array}$ \\
\hline 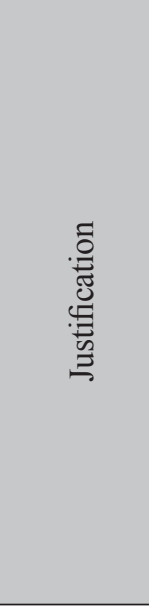 & $\begin{array}{l}\text { Our notion of education is usually one of class attendance, listening to trainers, } \\
\text { doing homework and taking exams. The educational content is designed either } \\
\text { formally or non-formally and is usually delivered in classrooms. Education, } \\
\text { however, is not only about delivering content however; it a more complex activ- } \\
\text { ity that involves the trainer-learner relationship and the relationship the learners } \\
\text { have with each other; informal learning happens during this interaction. } \\
\text { The informal skills and attitudes that can be acquired in these spaces are empa- } \\
\text { thy, assertiveness, ability to communicate, to negotiate and reach agreements. } \\
\text { Social skills can be acquired informally in every class, regardless of the subject } \\
\text { being taught. } \\
\text { All these social attitudes are necessary to attain support, friendship, collabora- } \\
\text { tion, help, to share, feel included, etc. Social skills are necessary to deal with } \\
\text { other people, some of them already known (family, friends), others still un- } \\
\text { known (new friends or colleagues) or strangers. }\end{array}$ \\
\hline
\end{tabular}




\begin{tabular}{|c|c|}
\hline Title & 10. Acquiring social attitudes informally \\
\hline 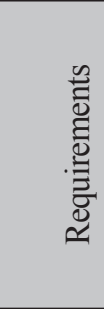 & $\begin{array}{l}\text { 1. Trainers and staff are aware of the possibilities of informal learning to gain } \\
\text { social skills and communicative attitudes. } \\
\text { 2. Trainers frequently make use of informal learning by designing activities or } \\
\text { facilitating interactions between learners, organising learners into groups for } \\
\text { different activities, debates, discussions, etc. } \\
\text { 3. Learners are aware and recognise that class attendance does not only mean } \\
\text { listening but also participating and being active. }\end{array}$ \\
\hline 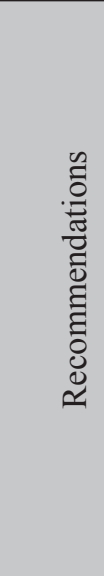 & $\begin{array}{l}\text { Informal learning has enormous potentialities, but it is difficult to control and pro- } \\
\text { vide adequately in a planned way: it is offered transversally by all the actors and } \\
\text { activities provided by the institution: } \\
\text {. Management: where they support provision of this model of education. } \\
\text { Institution: where their aims include increasing socialisation of learners in the } \\
\text { institution. } \\
\text { Trainer: being aware of informal education and having the necessary skills to } \\
\text { provide it. } \\
\text { Facilitators, tutors: creating the right environment for discussion and debate } \\
\text { when organising activities, groups of learners, other tasks such as extra-curric- } \\
\text { ular activities, etc., where social interaction develops. } \\
\text { Chapter } 4 \text { (Models of Education) of this guide gives the background to informal } \\
\text { learning and describes experiences of it. }\end{array}$ \\
\hline
\end{tabular}

\begin{tabular}{|c|c|}
\hline Title & 11. Formal learning provider \\
\hline Source & $\begin{array}{l}\text { Management } \\
\text { Internal regulation }\end{array}$ \\
\hline Edu. dim. & Models \\
\hline QoL dim. & Indirect transfer \\
\hline 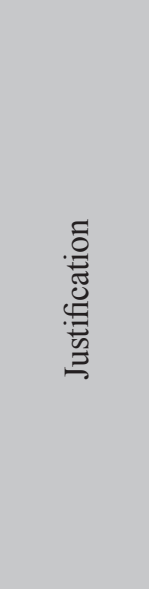 & $\begin{array}{l}\text { It is important that learners enrol in the subjects they most enjoy or are eager } \\
\text { to attend. However, other subjects must be included that may be more useful to } \\
\text { them, and that perhaps they may not enjoy as much, but that they must study in } \\
\text { order to gain general and comprehensive competences and skills. } \\
\text { The general skills and competences that all senior learners should acquire will } \\
\text { depend on the institution's aims, but they are also related to seniors'needs based } \\
\text { on QoL criteria. Those subjects and activities improve their knowledge of them- } \\
\text { selves (ageing process) and society, essentially aimed at increasing their QoL: } \\
\text { growth as an individual, being healthier, happier, and being integrated and par- } \\
\text { ticipative in their community and in society. } \\
\text { In institutions where subjects are not mandatory, learners should be offered ad- } \\
\text { vice about which subjects are the most appropriate for them. } \\
\text { If that formal structure is not ensured, then some learners could miss out on es- } \\
\text { sential knowledge and skills because they do not think a subject is interesting. }\end{array}$ \\
\hline
\end{tabular}




\begin{tabular}{|c|c|}
\hline Title & 11. Formal learning provider \\
\hline 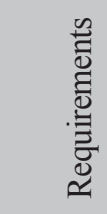 & $\begin{array}{l}\text { 1. There is an academic structure or plan with mandatory courses or activities, or } \\
\text { there is a procedure in place to advise learners and recommend specific courses } \\
\text { or activities for them to take. } \\
\text { 2. The selection of those mandatory courses and activities is justified and based on } \\
\text { institution aims and QoL criteria. }\end{array}$ \\
\hline 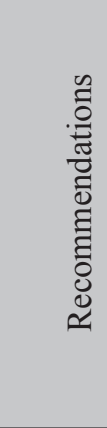 & $\begin{array}{l}\text { Some competences and skills can be common to all learners. Which subjects } \\
\text { are mandatory or recommended for learners depends on the general aims of the } \\
\text { institution, but although it is good for learners to have a free choice of subjects } \\
\text { they most want to study or most enjoy, learners should be offered help in mak- } \\
\text { ing that choice. } \\
\text { An academic plan of mandatory subjects or a counselling service must be in } \\
\text { place. } \\
\text { Chapter } 4 \text { of the guide describes good practice in "A proposal for a formal } \\
\text { course structure and its potentialities", which gives an example of mandatory } \\
\text { subjects structured in a three-year academic course. }\end{array}$ \\
\hline
\end{tabular}

\begin{tabular}{|c|c|}
\hline Title & 12. Formal learning groups \\
\hline Source & $\begin{array}{l}\cdot \text { Management } \\
\cdot \text { Internal regulation } \\
\cdot \text { Senior learners }\end{array}$ \\
\hline Edu. dim. & - Models \\
\hline QoL dim. & $\begin{array}{l}\text { Psychological health } \\
\text { - Social integration } \\
\text { - Personal growth } \\
\text { - Physical health }\end{array}$ \\
\hline .0 & $\begin{array}{l}\text { Learners attending courses must feel that they are part of a group and a commu- } \\
\text { nity; they are enrolled in the institution, but they also are members of it. Only } \\
\text { with that sense of community can a relationship between learners grow, thus } \\
\text { increasing support, integration and motivation to take part in activities together. } \\
\text { - The links between learners will grow, creating support groups related to any } \\
\text { area they may be interested in (health, doubts, problems, etc). }\end{array}$ \\
\hline 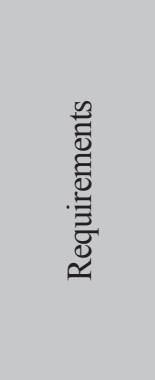 & $\begin{array}{l}\text { 1. Learners form groups because of the long-term relationships they have forged } \\
\text { through meeting each other on a regular basis. These groups allow them to in- } \\
\text { teract and communicate, to know each other better in the medium term (during } \\
\text { one academic year) or long term (more than an academic year). This process } \\
\text { also leads to the creation of small support groups over time. } \\
\text { 2. The learners feel that they are part of group in which they can give and receive } \\
\text { support, and that they have friends and colleagues in the educational institution. } \\
\text { 3. Seniors feel it is their duty to make changes to their timetables or activities } \\
\text { because of their friends' opinions and needs. }\end{array}$ \\
\hline
\end{tabular}




\begin{tabular}{|c|c|}
\hline Title & 12. Formal learning groups \\
\hline \multirow{3}{*}{ 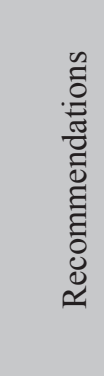 } & $\begin{array}{l}\text { Offer a long-term activity or course that encourages senior citizens to interact } \\
\text { with each other. This activity may last throughout the year. }\end{array}$ \\
\hline & $\begin{array}{l}\text { In the case of institutions that offer mandatory subjects for all learners (basic } \\
\text { competences everybody should acquire), mandatory subjects should be orga- } \\
\text { nised in such a way that the same group of learners continue to meet year after } \\
\text { year. }\end{array}$ \\
\hline & $\begin{array}{l}\text { The good practice "A proposal for a formal course structure and its potentia- } \\
\text { lities" in chapter } 4 \text { of the guide gives an example of a formal group and the } \\
\text { long-term benefits of this structure. }\end{array}$ \\
\hline
\end{tabular}

\begin{tabular}{|c|c|}
\hline Title & 13. Comprehensive educational activity \\
\hline \multirow{3}{*}{ Source } & $\cdot$ Management \\
\hline & - Internal regulation, offer of courses and activities \\
\hline & Senior learners \\
\hline Edu. dim. & - Model \\
\hline \multirow{4}{*}{ QoL dim. } & - Psychological health \\
\hline & $\cdot$ Control \\
\hline & - Personal fulfilment \\
\hline & · Personal growth \\
\hline \multirow{4}{*}{.气 } & $\begin{array}{l}\text { When organising educational activities, the heterogeneity of elderly people } \\
\text { should be kept in mind. A wide range of different types of activities should be } \\
\text { available to motivate and involve people. }\end{array}$ \\
\hline & $\begin{array}{l}\text { Optional courses and activities must be provided, allowing senior learners to } \\
\text { choose the ones they like most. They must also have the chance to enrol on } \\
\text { courses that, while not necessarily their main topic of interest, provide a broad } \\
\text { range of knowledge in all areas: health, science, law, economics and humanities. }\end{array}$ \\
\hline & $\begin{array}{l}\text { Apart from the variety of courses in all areas of knowledge, the delivery of those } \\
\text { courses should also be varied: lectures, theory classes, participatory classes, } \\
\text { workshops, and even virtual classes. }\end{array}$ \\
\hline & $\begin{array}{l}\text { - Variety in content and delivery mode is positive, but in all cases planning of ac- } \\
\text { tivities should be based on needs assessments and seniors' own personal prefe- } \\
\text { rences. }\end{array}$ \\
\hline \multirow{3}{*}{ 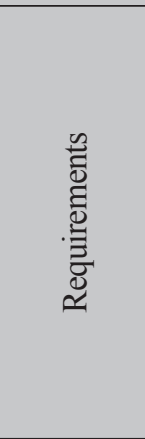 } & $\begin{array}{l}\text { 1. Education is provided (activities, courses, extra-academic activities, informal } \\
\text { activities, etc.) in a wide variety of areas (health, humanities, science, econo- } \\
\text { mics or law) and in a variety of delivery modes (lectures, theory classes, par- } \\
\text { ticipatory classes, workshops). }\end{array}$ \\
\hline & $\begin{array}{l}\text { 2. The educational activities have a dual purpose: learners acquire skills and com- } \\
\text { petences, and they are also designed and planned to match seniors' needs (e.g., } \\
\text { teaching real-life ICT, providing cases about issues learners will find useful). }\end{array}$ \\
\hline & $\begin{array}{l}\text { 3. The educational activities are tailor-made for senior learners. They encourage } \\
\text { socialisation and increased well-being, are important in preventing loneliness } \\
\text { and depression and, in general, are closely linked to quality-of-life issues. }\end{array}$ \\
\hline
\end{tabular}




\begin{tabular}{|c|c|}
\hline Title & 13. Comprehensive educational activity \\
\hline 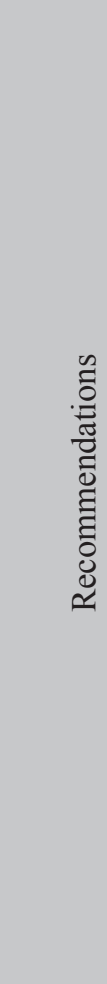 & $\begin{array}{l}\text { Organise different kinds of courses. Example: } \\
\cdot \text { ICT for seniors } \\
\cdot \text { Language courses } \\
\cdot \text { Sports activities (swimming, Nordic walking) } \\
\text { · Workshops } \\
\cdot \text { Cooking activities } \\
\cdot \text { Choirs } \\
\text { · Multicultural activities } \\
\cdot \text { Art and history } \\
\cdot \text { Economics and society } \\
\text { · Technology and science } \\
\text { For more information, see the experience "ICT for seniors" in the chapter } 6 \\
\text { of the guide. The ICT courses have at least three consequences for participants: } \\
\text { (1) they have helped older people to build up their self confidence in using the } \\
\text { new technology, (2) they have given them new possibilities to communicate with } \\
\text { their grandchildren and relatives abroad, and ( } 3 \text { ) they are also a type of cognitive } \\
\text { training. } \\
\text { See the experience "A proposal for a formal course structure and its potentialities" } \\
\text { in chapter } 4 \text { of the guide for an example of a variety of courses in several areas } \\
\text { and "Informal learning through leisure", also in chapter } 4 \text {, as an example of extra- } \\
\text { academic activities. }\end{array}$ \\
\hline
\end{tabular}

\begin{tabular}{|c|c|}
\hline Title & 14. Intergenerational learning \\
\hline Source & $\begin{array}{ll}\cdot & \text { Management } \\
\cdot & \text { Documentation (flyers, photos, reports) } \\
\cdot & \text { Trainers } \\
\cdot & \text { Senior learners }\end{array}$ \\
\hline Edu. dim. & $\begin{array}{ll}\cdot & \text { Model } \\
\cdot & \text { Activities }\end{array}$ \\
\hline QoL dim. & $\begin{array}{ll}\cdot & \text { Social integration } \\
\cdot & \text { Psychological health } \\
\cdot & \text { Control } \\
\text {. } & \text { Personal fulfilment } \\
\text {. } & \text { Personal growth }\end{array}$ \\
\hline
\end{tabular}




\begin{tabular}{|c|c|}
\hline Title & 14. Intergenerational learning \\
\hline Justification & $\begin{array}{l}\text { Intergenerational learning enables communicative and emotional } \\
\text { activities and experience exchange between generations. } \\
\text { Non-formal and informal learning occurs in this intergenerational } \\
\text { exchange, which is beneficial for both parties. } \\
\text { Seniors can feel more included in their families or in society in ge-- } \\
\text { neral not only by doing activities together, but by (informally) de- } \\
\text { veloping their knowledge about this sector of population. } \\
\text { During interaction with other generations, senior learners can learn } \\
\text { from children and younger people. }\end{array}$ \\
\hline Requirements & $\begin{array}{l}\text { 1. There is at least one activity involving seniors and younger citi- } \\
\text { zens (other generations). } \\
\text { 2. The activity is designed so both generations learn non-formally } \\
\text { and informally; the activity is suitable and lasts long enough to } \\
\text { facilitate interaction between generations. }\end{array}$ \\
\hline 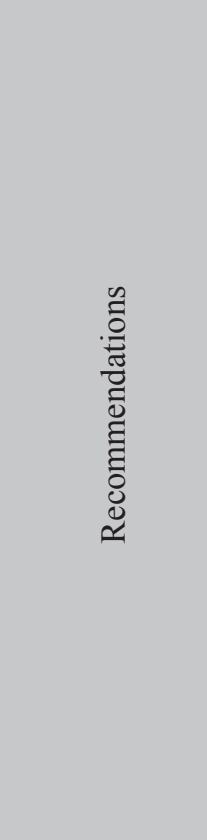 & $\begin{array}{l}\text { Senior citizens' extensive life experience can be mined for ac- } \\
\text { tivities that they can teach to younger generations. The challenge } \\
\text { lies in selecting the most suitable topic and place for the activity; } \\
\text { if the wrong choices are made, it may be regarded as being no } \\
\text { different from any other traditional teaching process. } \\
\text { The activity should not be unidirectional, should allow both par- } \\
\text { ties to participate, and should include informal components such } \\
\text { as learning attitudes and habits. } \\
\text { Offer a non-traditional environment outside the institution, for } \\
\text { instance, somewhere near water where they can light a fire, drink } \\
\text { tea together, watch the sunset, etc. } \\
\text { Another suggestion is to combine history and storytelling to } \\
\text { children, focusing on differences in habits and customs, thus al- } \\
\text { lowing both parties to discover new attitudes and behaviours. } \\
\text { Seniors may be interested in engaging with each other and their } \\
\text { families to gather information to create a family tree. } \\
\text { For an example of intergenerational education, see the experience "El- } \\
\text { derly people now online: school in the afternoon project" in chapter } 7 \\
\text { of the guide. }\end{array}$ \\
\hline
\end{tabular}




\subsection{PEDAGOGY}

The educational dimension of "Pedagogy" concerns the way techniques and educational methods are applied to courses and activities.

\begin{tabular}{|c|c|}
\hline Title & 15. Constructive pedagogy \\
\hline \multirow{2}{*}{ Source } & Trainers \\
\hline & - Senior learners \\
\hline Edu. dim. & · Pedagogy \\
\hline \multirow{3}{*}{ QoL dim. } & · Personal growth \\
\hline & · Personal fulfilment \\
\hline & Control \\
\hline \multirow{3}{*}{ : } & $\begin{array}{l}\text { Learning must involve the learner not only as a mere recipient of infor- } \\
\text { mation, but as a person with a wealth of life experience that can be used to } \\
\text { facilitate the teaching-learning process, and which the learner discovers } \\
\text { by himself or herself. }\end{array}$ \\
\hline & $\begin{array}{l}\text { Learning must be also addressed to increase learners' other competences, } \\
\text { applied through constructivist theories: discover by oneself, learn frompast } \\
\text { experiences, analyse problems, try to find solutions and learn from diff- } \\
\text { culties instead of becoming blocked. }\end{array}$ \\
\hline & $\begin{array}{l}\text { In this way, constructivism can be applied not only to learn specific sub- } \\
\text { jects, but to acquire other capacities that can be useful in other situations. }\end{array}$ \\
\hline \multirow{2}{*}{ 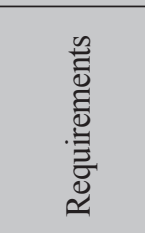 } & $\begin{array}{l}\text { 1. Trainers are aware of constructivist theory and its characteristics and } \\
\text { potentialities. }\end{array}$ \\
\hline & $\begin{array}{l}\text { 2. When the topic of a subject or activity allows it, constructivism is ap- } \\
\text { plied by providing tasks and exercises designed to make learners think } \\
\text { and discover by themselves (trainers act as facilitators). }\end{array}$ \\
\hline \multirow{4}{*}{ 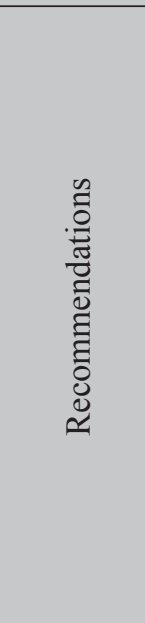 } & $\begin{array}{l}\text { Propose subjects and activities where trainers act as facilitators of learn- } \\
\text { ing by providing information, but the learner has to discover and select } \\
\text { which information is useful. }\end{array}$ \\
\hline & $\begin{array}{l}\text { Plan debates, workshops, discussions etc., on topics that can be contro- } \\
\text { versial or that affect society or the learners' lives. These activities allow } \\
\text { learners to interact and share ideas, by accepting or negotiating, disco- } \\
\text { vering new points of view and different perspectives. }\end{array}$ \\
\hline & $\begin{array}{l}\text { Motivate learners to critical thinking, analysis, synthesis, logical pro- } \\
\text { cessing, creating links with other facts or aspects, discovering impacts } \\
\text { on other facets or dimensions of life. Train not only to grasp the super- } \\
\text { ficial idea, or summarise texts or news, but to learn to extract hidden } \\
\text { content and explore and test new ideas. }\end{array}$ \\
\hline & $\begin{array}{l}\text { See chapter } 5 \text { on pedagogy and the experience "New knowledge to get new in- } \\
\text { formation" for further advice. }\end{array}$ \\
\hline
\end{tabular}




\begin{tabular}{|c|c|}
\hline Title & 16. Learn by research \\
\hline Source & $\begin{array}{ll}\cdot & \text { Trainers } \\
\cdot & \text { Internal regulation, list of courses } \\
\cdot & \text { Senior learners }\end{array}$ \\
\hline Edu. dim. & $\begin{array}{l}\text { Pedagogy } \\
\text { Activity }\end{array}$ \\
\hline QoL dim. & $\begin{array}{l}\text { Participation } \\
\text {. Personal growth } \\
\text {. Personal fulfilment } \\
\text {. }\end{array}$ \\
\hline Justification & $\begin{array}{l}\text { Applying "learning by research" pedagogy to courses or activities in- } \\
\text { creases creativity, and a sense of being productive, active and useful. } \\
\text { Learners then discover something by themselves, which makes them } \\
\text { feel proud and useful, and increases their self-esteem. } \\
\text { "Learning by research" does not set out to perform scientific re- } \\
\text { search, but to increase learners' decision-making capacity and inde- } \\
\text { pendence. During this activity students learn about the topic itself, } \\
\text { but also new skills related to participation, control, decision making } \\
\text { and organisation. }\end{array}$ \\
\hline Requirements & $\begin{array}{l}\text { 1. The institution promotes learning by research pedagogy: completely } \\
\text { self-directed learning with the supervision of a trainer or tutor. There } \\
\text { is at least one subject or activity that applies it, or courses that include } \\
\text { this kind of task in their academic programme. } \\
\text { 2. The results of this activity are presented publicly and disseminated } \\
\text { in society. } \\
\text { 3. In general, wherever possible learners should find information or } \\
\text { data, or solve their questions from the environment (independently) } \\
\text { by using libraries, internet, asking others etc. }\end{array}$ \\
\hline 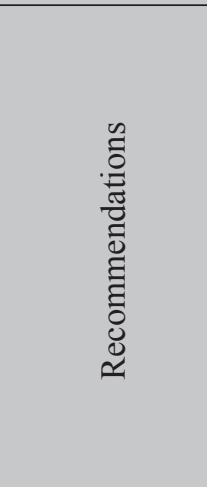 & $\begin{array}{l}\text { Propose subjects and activities where the tutors guide and help learn- } \\
\text { ers to research topics they are interested in. } \\
\text { - Facilitators must also motivate learners and provide sources of in- } \\
\text { formation. } \\
\text {. The research outcome should eventually be made public (published } \\
\text { on a website, in a conference, etc), potentially maximising the impact } \\
\text { of the task on classmates, but also on the learner, who has reached } \\
\text { that milestone on his or her academic path. } \\
\text { An example of learning by research is described in the experience "A pro- } \\
\text { posal for a formal course structure and its potentialities" where learners } \\
\text { carry out a tutored research project at the end of their third year. }\end{array}$ \\
\hline
\end{tabular}




\begin{tabular}{|c|c|}
\hline Title & 17. Participatory pedagogy \\
\hline Source & $\begin{array}{ll}\text { Trainers } \\
\text {. } & \text { Learners }\end{array}$ \\
\hline Edu. dim. & - Pedagogy \\
\hline QoL dim. & $\begin{array}{ll}\cdot & \text { Control } \\
\cdot & \text { Participation } \\
\cdot & \text { Social }\end{array}$ \\
\hline Justification & $\begin{array}{l}\text { When the trainer explains something in class, learners should } \\
\text { be given a way of adding some value to the explanations. While } \\
\text { participation should be moderated, an opportunity must always } \\
\text { be given to ask questions or make comments. This participation } \\
\text { in class is the first step to increasing participation and commu- } \\
\text { nication in other activities, and subsequently in society. } \\
\text { Trainers can also ask shy learners or those who think they } \\
\text { have no opinion for their views. This helps to increase their } \\
\text { perceived control, and learners then become aware that their } \\
\text { opinions are important. }\end{array}$ \\
\hline Requirements & $\begin{array}{l}\text { 1. Learners feel free to participate in class when they have a doubt } \\
\text { or a question; they can also add information and trainers are } \\
\text { keen to discuss any aspect of the subject with them. } \\
\text { 2. Trainers allow and encourage feedback among learners by mod- } \\
\text { erating and providing useful information, particularly when it is } \\
\text { necessary to contradict or argue with a learner. }\end{array}$ \\
\hline 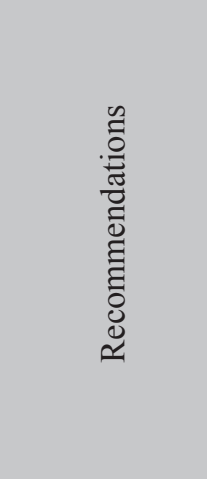 & $\begin{array}{l}\text { Trainers should encourage learners to participate during class. } \\
\text { Even in formal talks or theoretical lectures, a turn for questions } \\
\text { should be built in. } \\
\text { When learners provide feedback (a question, or a suggestion) } \\
\text { trainers must have the necessary skills to resolve the ques- } \\
\text { tion, and accept or reject the suggestion as appropriate. This } \\
\text { exchange should be made appropriately, by balancing nego- } \\
\text { tiation between learner-trainer but also taking into account the } \\
\text { trainer's authority. } \\
\text { Trainers must have sufficient skills not only in their own sub- } \\
\text { ject, but also in communication. }\end{array}$ \\
\hline
\end{tabular}




\begin{tabular}{|c|c|}
\hline Title & 18. Learn to learn \\
\hline \multirow{2}{*}{ Source } & Trainer \\
\hline & - Learner \\
\hline $\begin{array}{l}\text { Edu. } \\
\text { dim. }\end{array}$ & · Pedagogy \\
\hline \multirow{3}{*}{$\begin{array}{l}\text { QoL } \\
\text { dim. }\end{array}$} & · Participation \\
\hline & · Control \\
\hline & . Personal growth \\
\hline \multirow{3}{*}{ 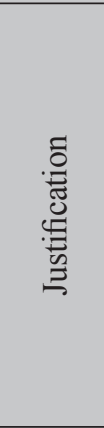 } & $\begin{array}{l}\text { Learning should not end when students leave the institution. They can always learn in- } \\
\text { formally outside classrooms, with their families and through what happens around them. }\end{array}$ \\
\hline & $\begin{array}{l}\text { Learners should acquire skills to understand what is happening (analysing), and to adapt } \\
\text { to changes and interact with other people, all of which increase their perceived control } \\
\text { and participation. }\end{array}$ \\
\hline & $\begin{array}{l}\text { "Learning to learn" is an aptitude that can be promoted while teaching any course or } \\
\text { in any participatory activity. It is related to the skills needed to find and ask for help, } \\
\text { information or support, and in turn, to provide it. It is also related to curiosity, motivation } \\
\text { and eagerness to learn new things. When learners are facing difficulties, it is useful to } \\
\text { have a positive attitude. }\end{array}$ \\
\hline \multirow{2}{*}{ 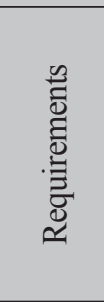 } & $\begin{array}{l}\text { 1. Trainers are aware of the "learning to learn" principles and encourage learners to keep } \\
\text { learning and exploring once the class ends. Trainers provide exercises or propose tasks } \\
\text { to do outside the classroom. }\end{array}$ \\
\hline & $\begin{array}{l}\text { 2. Learners (in general) feel they are more motivated to learn new subjects, read } \\
\text { or talk about topics they were not previously interested in. They feel more confident to } \\
\text { talk about or discuss topics outside the comfort zone of their own environment } \\
\text { (family, friends, former workmates). }\end{array}$ \\
\hline \multirow{5}{*}{ 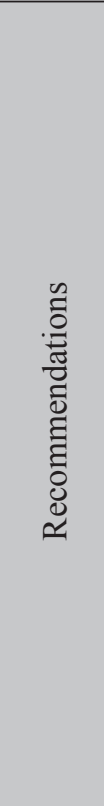 } & $\begin{array}{l}\text { "Learning to learn" aims to turn senior learners into self-learners who ask for and give } \\
\text { help. This is achieved by acquiring reading and comprehensive skills, being able to un- } \\
\text { derstand available information, but also knowing how to apply it or transfer it to our } \\
\text { own lives. }\end{array}$ \\
\hline & $\begin{array}{l}\text { In theoretical subjects such as psychology, philosophy, sociology, arts or history, under- } \\
\text { standing can be easy so long as the information is addressed to the general public, but it } \\
\text { is important to have the skill to transfer this information into one's own personal area of } \\
\text { expertise. In more practical subjects such as ICT, it is more difficult to be a self-learner; } \\
\text { it is important to learn how to ask the right questions and help other learners. }\end{array}$ \\
\hline & $\begin{array}{l}\text { Finally, trainers should provide sources of information and ways of obtaining support } \\
\text { in cases of doubt or questions. Internet is a very good source of information, but it must } \\
\text { be used in the right way: questions must be asked correctly, and learners must have the } \\
\text { necessary skills to differentiate between trustworthy and unreliable information. }\end{array}$ \\
\hline & $\begin{array}{l}\text { Seniors should also be aware that any problem or challenge they face in their lives can } \\
\text { be a positive experience they can learn from. }\end{array}$ \\
\hline & $\begin{array}{l}\text { In the developing knowledge society, it is as important to have access to sources of } \\
\text { information, as to know what we are looking for, where we can look for it, and what we } \\
\text { can do once we find it. It may be useful to include a course to promote the "learning to } \\
\text { learn" attitude. }\end{array}$ \\
\hline
\end{tabular}




\subsection{COURSES}

"Courses" refer to any kind of learning processes where a teacher is involved and has a related teaching plan, even if that plan has not been formally established (content, competences to be achieved, pedagogy, timing, objectives, evaluation), for example:

- practical, formal courses, such as ICT and language courses, where learners acquire mainly practical skills

- more formal or theoretical courses, such as economics, sociology, philosophy, history, arts, etc., where learners acquire specific knowledge of understanding in those areas

- more informal courses, such as cooking, handicrafts, dancing, choir, theatre group etc. (where a teaching plan is in place).

\begin{tabular}{|c|c|}
\hline Title & 19. Competences for life changes \\
\hline Source & $\begin{array}{l}\text { Pedagogical plan } \\
\text { - Internal regulation, management } \\
\text { - Senior learners }\end{array}$ \\
\hline Edu. dim. & - Courses \\
\hline QoL dim. & $\begin{array}{l}\text { - Control } \\
\text { · Personal fulfilment } \\
\text {. } \\
\text { Personal growth }\end{array}$ \\
\hline Justification & $\begin{array}{l}\text { Although getting older is something that happens gradually, certain events } \\
\text { or situations can sometimes catch seniors unexpectedly, mostly because } \\
\text { they are not aware or sometimes because another sudden event triggers a } \\
\text { reaction or a loss of control. } \\
\text { - Those changes can be gradual, such as changing roles in the family, less } \\
\text { activity or social contact, reduced physical and mental capacity, etc.; or } \\
\text { sudden, like the death of a friend or spouse, change of habits, house } \\
\text { or neighbourhood, etc. } \\
\text { To lower all the risks that jeopardize QoL, individuals can acquire the } \\
\text { competences they need to know about themselves, so each person can } \\
\text { detect his or her potentialities, and attempt to dispel negative thoughts by } \\
\text { learning how to adapt and adjust to the environment. }\end{array}$ \\
\hline
\end{tabular}




\begin{tabular}{|c|c|}
\hline Title & 19. Competences for life changes \\
\hline Requirements & $\begin{array}{l}\text { 1. At least one course is designed to provide senior learners with knowledge } \\
\text { about the ageing process and the skills to cope with change. } \\
\text { 2. This course contains material taken from philosophy, sociology and psy- } \\
\text { chology, but pitched at a simple level and easily applied to learners' every- } \\
\text { day general experiences. } \\
\text { 3. The learners attending this course feel they have more control over nega- } \\
\text { tive feelings and worries and are more capable of enjoying life. }\end{array}$ \\
\hline 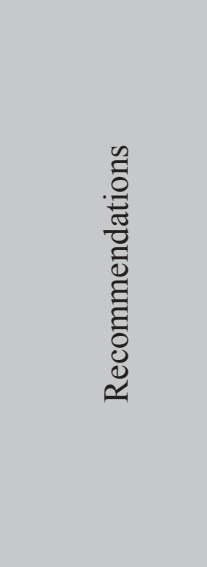 & $\begin{array}{l}\text { Theoretical concepts should be provided from several areas: philosophy } \\
\text { (acceptance of oneself and others, tolerance, diversity, cultural concepts } \\
\text { of human beings); from sociology (the ageing process in today's society, } \\
\text { views and perceptions of the elderly, new family structures); and from } \\
\text { psychology (the process of getting older, interpersonal relations, affection, } \\
\text { self-concept). } \\
\text { There are numerous self-help books that can easily be adapted for senior } \\
\text { learners. Explaining through stories or other fictional situations can help } \\
\text { them to discover negative situations in their lives that affect themselves } \\
\text { and their families. } \\
\text { Chapter } 4 \text { of the guide describes the experience "A proposal for a formal } \\
\text { course structure and its potentialities", which suggests subjects in the area of } \\
\text { psychology, sociology and philosophy. }\end{array}$ \\
\hline
\end{tabular}

\begin{tabular}{|c|c|}
\hline Title & 20. Digital adoption \\
\hline Source & $\begin{array}{ll}\cdot & \text { Pedagogical plan } \\
\text {. } & \text { Internal regulation, management } \\
\text {. } & \text { Senior learners }\end{array}$ \\
\hline Edu. dim. & - Courses \\
\hline QoL dim. & $\begin{array}{l}\text { Increase participation } \\
\text {. } \\
\text { Personal fulfilment } \\
\text { Personal growth }\end{array}$ \\
\hline Justification & $\begin{array}{l}\text { Learners' increased use of ICT facilitates their communication with fa- } \\
\text { mily, relatives and friends. They can participate more actively in these } \\
\text { groups and in society. } \\
\text { As ICT is becoming more widespread in today's society, communication, } \\
\text { sharing information and collaboration are now required skills for inclu- } \\
\text { sion in social groups. } \\
\text { Communication using ICT also offers great opportunities to extend the } \\
\text { support network, and at the same time it can be considered as a leisure } \\
\text { activity. }\end{array}$ \\
\hline
\end{tabular}




\begin{tabular}{|c|c|}
\hline Title & 20. Digital adoption \\
\hline Requirements & $\begin{array}{l}\text { 1. At least one course is offered to increase learners' ICT skills, but also aims } \\
\text { to increase ITC use for personal purposes in learners' own communities } \\
\text { (friends, family, etc). } \\
\text { 2. Several groups are available according to level. } \\
\text { 3. Learners feel that they can use ICT to communicate or look for informa- } \\
\text { tion and are comfortable with that (they do not avoid this mode of com- } \\
\text { munication or technology). } \\
\text { 4. The number of students that use ICT tools is much higher than the average } \\
\text { for the general population above } 65 \text {. }\end{array}$ \\
\hline 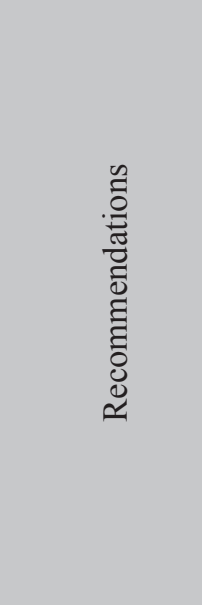 & $\begin{array}{l}\text { Offer practical subjects to learners, where they can bring their needs and } \\
\text { experiences. All learners should be assigned an electronic mail account. } \\
\text { Trainers' should be helped to extend their knowledge about learners' ex- } \\
\text { periences and needs, why they need ICT and how they can make more } \\
\text { effective use of technology, especially communicative tools, social net- } \\
\text { works, searching on the net, examples of available services and infor- } \\
\text { mation, sharing photos or other information, and also information about } \\
\text { security. } \\
\text { The institution should also use ICT for providing information and com- } \\
\text { municating with learners. This creates a very familiar environment where } \\
\text { inexperienced learners can feel confident and practise. } \\
\text { Chapter } 6 \text { of the guide describes the experience "ICT for seniors", which } \\
\text { shows ICT as a tool but also as a way of helping to integrate a multicul- } \\
\text { tural group of learners enrolled on the same course. }\end{array}$ \\
\hline
\end{tabular}

\begin{tabular}{|l|l|}
\hline Title & 21. Physical well-being \\
\hline Source & $\begin{array}{l}\cdot \text { Pedagogical plan } \\
\cdot \text { Internal regulation, management } \\
\text { - Senior learners }\end{array}$ \\
\hline Edu. dim. & $\begin{array}{l}\cdot \text { Courses } \\
\text { Q Activities }\end{array}$ \\
\hline & $\begin{array}{l}\cdot \text { Physical health } \\
\text { QoL dim. }\end{array}$
\end{tabular}




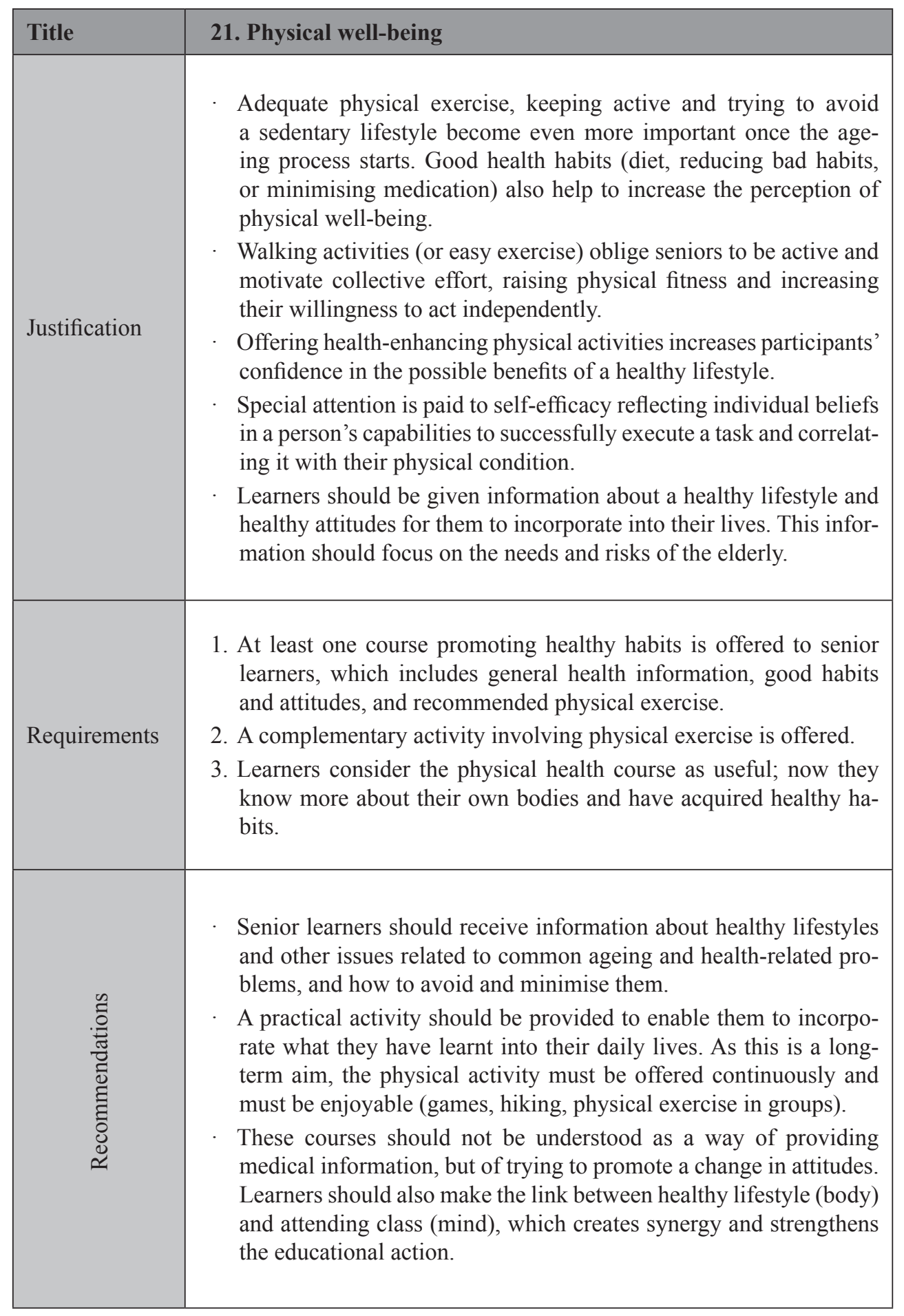




\begin{tabular}{|c|c|}
\hline Title & 22. Languages \\
\hline Source & $\begin{array}{l}\text { Pedagogical plan } \\
\text { Internal regulation, management } \\
\text { Trainers } \\
\text { Senior learners }\end{array}$ \\
\hline Edu. dim. & Courses \\
\hline QoL dim. & $\begin{array}{l}\text { Participation } \\
\text { Social integration } \\
\text { Psychological health }\end{array}$ \\
\hline Justification & $\begin{array}{l}\text { In a global society where technology is part of everyday life and foreign } \\
\text { travel is increasingly commonplace, language courses should be offered } \\
\text { so students can learn and feel part of society, enabling them to communi- } \\
\text { cate and feel confident. } \\
\text { Language teaching can also be used to develop strategies of communica- } \\
\text { tion, autonomous learning and autonomy development, improving learn- } \\
\text { ers' self-esteem and self-confidence, increasing awareness and know- } \\
\text { ledge of other countries, cultures, customs and traditions. } \\
\text { Learning a new language is a cognitive activity that forces several parts } \\
\text { of the brain to work simultaneously to acquire a new skill. This activity is } \\
\text { considered as a "brain training" process. }\end{array}$ \\
\hline 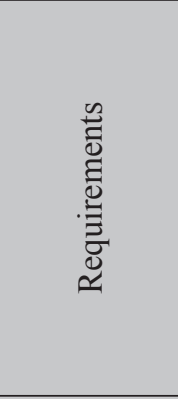 & $\begin{array}{l}\text { 1. The course programme offers at least one language course aimed at in- } \\
\text { creasing learners' foreign language skills and also designed to stimulate } \\
\text { the practical use of that language. } \\
\text { 2. Several groups are available according to level. The course should focus } \\
\text { on specific communication skills for the elderly (not commercial English, } \\
\text { for example). } \\
\text { 3. Learners feel their language skills have improved and that the training } \\
\text { has helped them develop their self-esteem and enhance their interpersonal } \\
\text { and communication skills. }\end{array}$ \\
\hline 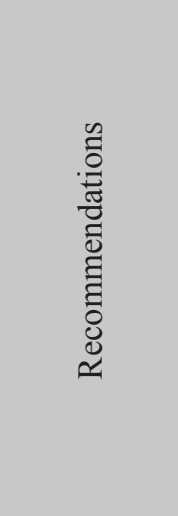 & $\begin{array}{l}\text { Train the trainers in the didactic, methodological and social skills and } \\
\text { competences they need to work with this specific target group. Select } \\
\text { training material appropriate for the age group. } \\
\text { Provide learners with rationale, justification and proof of why knowing } \\
\text { how to communicate in other languages will improve their personal, in- } \\
\text { terpersonal and communication skills. Apply techniques to motivate se- } \\
\text { nior learners to learn a foreign language. } \\
\text { Bring cultural aspects into the language training provision. Encourage } \\
\text { participation, empowerment, inclusion and development of intercultural } \\
\text { skills. } \\
\text { Focus on collaborative, self-conducted and situated learning, and problem- } \\
\text {-solving approaches to learning. }\end{array}$ \\
\hline
\end{tabular}




\begin{tabular}{|c|c|}
\hline Title & 23. Problem-based learning \\
\hline Source & $\begin{array}{ll} & \text { Senior learners } \\
\cdot & \text { Trainers } \\
\cdot & \text { Pedagogical plan }\end{array}$ \\
\hline Edu. dim. & . Courses \\
\hline QoL dim. & $\begin{array}{l}\text { Perceived control } \\
\text {. Social integration }\end{array}$ \\
\hline Justification & $\begin{array}{l}\text { This type of teaching increases participants' motivation to find } \\
\text { a solution to a given problem. Participants are required to work } \\
\text { together and everyone uses their strong points to add value dur- } \\
\text { ing the task. } \\
\text { If new fields of activity are involved in the case study, students } \\
\text { need to be creative, they need to think and then present their } \\
\text { findings and solutions. As a result of working successfully on } \\
\text { these case studies students will become more informed, confi- } \\
\text { dent and sociable. }\end{array}$ \\
\hline Requirements & $\begin{array}{l}\text { 1. At least one course or several courses have a significant part in } \\
\text { which seniors work collaboratively to find solutions to specific } \\
\text { problems. } \\
\text { 2. On this course, students work as a group, negotiate, discuss and } \\
\text { present the results to the rest of the classes. Learners feel at ease } \\
\text { when presenting the results. } \\
\text { 3. The topics and problems dealt with on this course are current } \\
\text { affairs issues, news, controversial events and advances. } \\
\text { 4. The trainer acts as a facilitator for discussion and debate and } \\
\text { also as a mediator to reach agreements and to ensure that the } \\
\text { discussion progresses to a constructive conclusion. }\end{array}$ \\
\hline Recommendations & $\begin{array}{l}\text { Motivate trainers to apply problem-based tasks in their subjects. } \\
\text { Provide continuously renewable topics, current or controversial } \\
\text { social topics that help seniors to acquire new perspectives and } \\
\text { opinions. } \\
\text { Provide help and instructions if students seem confused or puz- } \\
\text { zled, motivate learners to give their opinion and help to con- } \\
\text { struct positions of agreement. } \\
\text { Encourage participants during and after their speech and pre- } \\
\text { sentation. } \\
\text { Do not use this method too often to avoid it becoming repeti- } \\
\text { tious. }\end{array}$ \\
\hline
\end{tabular}




\begin{tabular}{|c|c|}
\hline Title & 24. Psychological well-being \\
\hline Source & $\begin{array}{l}\text { Senior learners } \\
\text { Trainers } \\
\text { Pedagogical plan }\end{array}$ \\
\hline Edu. dim. & $\begin{array}{ll}\text { - } & \text { Courses } \\
\text {. } & \text { Activity }\end{array}$ \\
\hline QoL dim. & $\begin{array}{l}\text { Psychological health } \\
\text { Personal growth } \\
\text { Personal fulfilment } \\
\text { Perceived control }\end{array}$ \\
\hline Justification & $\begin{array}{l}\text { Everybody can be flooded with negative thoughts and emotions } \\
\text { (like anger, feeling guilty, loss of control, worries or unfounded } \\
\text { fears etc.). Seniors are no exception, especially when their role } \\
\text { in life or in their environment changes. These negative thoughts } \\
\text { and emotions should be controlled and avoided when they are } \\
\text { unfounded or there is no need to worry. People have to learn to } \\
\text { explore and emphasise positive feelings. } \\
\text { The purpose of using relaxation techniques with seniors is to } \\
\text { reach a state of relaxation in order to control symptoms of anxi- } \\
\text { ety, help to reduce stress and foster belief in their ability to cope } \\
\text { in a difficult situation. This can be achieved by physical exercise } \\
\text { and promoting mental health. Over time stress has a very nega- } \\
\text { tive impact on seniors' health status. }\end{array}$ \\
\hline Requirements & $\begin{array}{l}\text { 1. At least one course aims to provide learners with the skills to cope } \\
\text { with stress and dispel negative thoughts. } \\
\text { 2. Learners do not perceive class attendance as a stressful activity } \\
\text { (they do not confuse it with being busy or active). } \\
\text { 3. Learners perceive less stress and anxiety; they have fewer nega- } \\
\text { tive thoughts, or at least they are better able to control them. }\end{array}$ \\
\hline Recommendations & $\begin{array}{l}\text { The trainer should use relaxation techniques in the classroom, } \\
\text { including physical activities and other strategies that encourage } \\
\text { optimism and facilitate coping with stress. Class learning should } \\
\text { not be stressful (caused by the amount of materials, homework, } \\
\text { discussion, debates, etc). } \\
\text { Some negative thoughts and emotions (guilt, self-criticism, ex- } \\
\text { cessive fear, anger, etc.) can become common in the ageing pro- } \\
\text { cess, or when seniors have too many family responsibilities or a } \\
\text { new role in the family. Seniors benefit from knowing how com- } \\
\text { mon those feelings are and how they can avoid and control them. }\end{array}$ \\
\hline
\end{tabular}




\begin{tabular}{|c|c|}
\hline Title & 25. Cultural trips \\
\hline Source & $\begin{array}{l}\text { Senior learners } \\
\text { Managers } \\
\text { Pedagogical plan }\end{array}$ \\
\hline Edu. dim. & $\begin{array}{l}\text { Courses } \\
\text { Activities }\end{array}$ \\
\hline QoL dim. & $\begin{array}{l}\text { Personal fulfilment } \\
\text { Social integration } \\
\text { Control }\end{array}$ \\
\hline 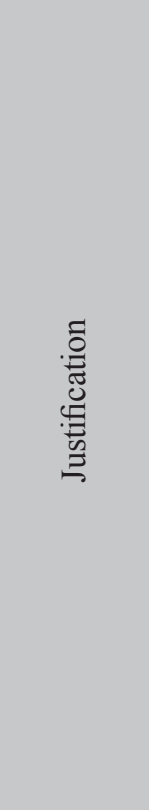 & $\begin{array}{l}\text { Some senior learners have not had the chance to travel or go abroad regularly. } \\
\text { Travelling can be a very pleasurable experience when it is done in the compa- } \\
\text { ny of people with common interests, with a group of people who already know } \\
\text { each other or organised by an institution in which the senior learner trusts. } \\
\text { A good way of organising holidays and weekend trips is by bringing together } \\
\text { seniors from different institutions. These trips allow seniors to spend time hav- } \\
\text { ing fun together, expand their knowledge of the region, get to know each other } \\
\text { better, and form and strengthen friendships. } \\
\text { Trips should have some cultural and educational content (visits to museums, } \\
\text { historical buildings, etc). However, it should be made clear that the educatio- } \\
\text { nal institution is not a travel agency. Activities organised outside the classroom } \\
\text { with friends, communing with nature, in museums, or other cultural places } \\
\text { consolidate the benefits of learning in class, and in this way, create the feeling } \\
\text { among learners that attitudes, social and communication skills and the rules of } \\
\text { coexistence are not only applied in the classroom. } \\
\text { Time spent outside the classroom gives the opportunity to acquire environ- } \\
\text { mental competences (green attitudes), spatial skills (localisation), learning } \\
\text { skills (observation) and social skills (freedom, independence, responsibility, } \\
\text { organisation, peaceful attitudes). }\end{array}$ \\
\hline 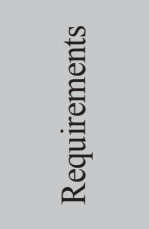 & $\begin{array}{l}\text { 1. At least one cultural trip is organised per year, with a minimum of one night } \\
\text { away from home where learners have to get along together in a shared space } \\
\text { for longer than usual. } \\
\text { 2. The trip includes cultural and educational activities, but also leisure activities } \\
\text { (not aimed at learning, but informal). }\end{array}$ \\
\hline 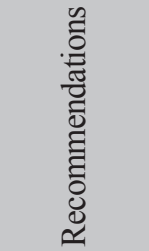 & $\begin{array}{l}\text { Take advantage of specific places, events or cultural activities in nearby cities } \\
\text { by organising trips that combine educational and leisure activities. } \\
\text { These activities should not be completely free, as learners may not see } \\
\text { the activity as a valuable experience. They should pay part of the costs, while the } \\
\text { institution can try to find funding from other sources to make up the remainder. }\end{array}$ \\
\hline
\end{tabular}




\subsection{ACTIVITIES}

"Activities" refer to any kind of learning process where a teacher is not involved continuously and no teaching plan is in place, for example:

- a website, conference or any dissemination activity;

- research or project-related activities;

- trips organised by learners, lunches, dinners, other social events;

- extra-academic activities such as a choir or theatre group (where it is organised as a leisure activity)

\begin{tabular}{|c|c|}
\hline Title & 26. Informal learning outside the classroom \\
\hline Source & - Senior learners \\
\hline Edu. dim. & $\begin{array}{l}\text { Courses } \\
\text {. Activities }\end{array}$ \\
\hline QoL dim. & $\begin{array}{l}\text { Psychological health } \\
\text {. Physical health }\end{array}$ \\
\hline 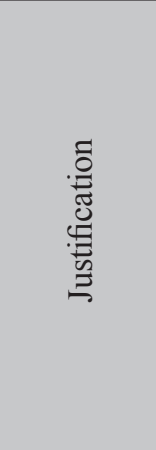 & $\begin{array}{l}\text { The mostly theoretical knowledge provided in classrooms should be ac- } \\
\text { companied by practical in-the-field information. Whatever the subject is, it } \\
\text { should be possible to link part of the content with an activity outside the } \\
\text { educational institution, thus emphasising practical learning outside the class- } \\
\text { room. } \\
\text { - The activities done outside the classroom offer a good chance to comple- } \\
\text { ment and acquire other competences such as being in open spaces (physi- } \\
\text { cally and psychologically) where people lose their inhibitions and act more } \\
\text { independently. } \\
\text { - Seniors should be aware that everywhere is a good place to learn, dispelling } \\
\text { the idea that learning only takes place in the classroom. }\end{array}$ \\
\hline 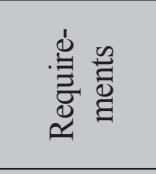 & $\begin{array}{l}\text { 1. There is at least one course in which a significant part consists of learning } \\
\text { activities outside the classroom. } \\
\text { 2. The pedagogical design of these courses takes advantage of being outside the } \\
\text { classroom to acquire competences that cannot be learned in ordinary classes. }\end{array}$ \\
\hline 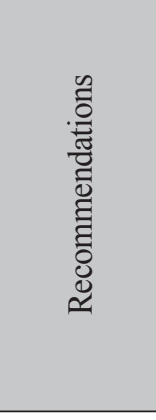 & $\begin{array}{l}\text { Cultural activities organised in uncontrolled and unknown spaces provide a } \\
\text { good chance for seniors to develop skills when they have to deal with other } \\
\text { elements in the environment. At the same time they have the opportunity to } \\
\text { learn by observing or discovering. } \\
\text { Such activities may involve visiting a specific place to gather information (in } \\
\text { subjects like botany, geology) or conduct research (to ask people, look for } \\
\text { information in libraries). } \\
\text { Ideally, these activities should complement some subjects that are taught in } \\
\text { the classroom; in this way a theoretical background is first introduced and } \\
\text { then put into practise. }\end{array}$ \\
\hline
\end{tabular}




\begin{tabular}{|c|c|}
\hline Title & 27. Increase in cognitive skills \\
\hline Source & $\begin{array}{l}\text { - Seniors } \\
\text {. Trainers }\end{array}$ \\
\hline Edu. dim. & $\begin{array}{l}\text { Courses } \\
\text { - Activities }\end{array}$ \\
\hline QoL dim. & Psychological health \\
\hline Justification & $\begin{array}{l}\text { Many studies have shown that Alzheimer disease and related disorders } \\
\text { is one of the greatest fears among older people. } \\
\text { Exercises can help to reduce cognitive decline, but where decline is in- } \\
\text { evitable other skills, habits and tactics can be acquired to compensate it. } \\
\text { To cope with changes, it must be understood which changes in mem- } \\
\text { ory and other cognitive functions are normal and abnormal during the } \\
\text { ageing process. It is also important to learn how to communicate with } \\
\text { friends with dementia. }\end{array}$ \\
\hline Requirements & $\begin{array}{l}\text { 1. There is at least one course that provides educational sessions about } \\
\text { normal and abnormal cognitive ageing processes. } \\
\text { 2. This course deals with possible ways of preventing cognitive and re- } \\
\text { lated disorders. }\end{array}$ \\
\hline 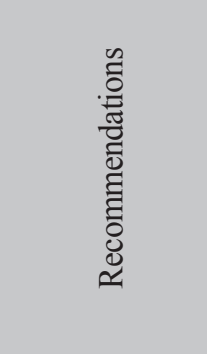 & $\begin{array}{l}\text { Seniors should be aware of the changes in cognitive ageing and of the } \\
\text { possible ways to halt them or slow them down. They can also learn } \\
\text { about other resources or techniques. } \\
\text { "Brain training" exercises can be provided to do in the classroom, but } \\
\text { seniors should also be encouraged to do these exercises and other cog- } \\
\text { nitive games at home (e.g., chess, computer games, learning a new lan- } \\
\text { guage). }\end{array}$ \\
\hline
\end{tabular}




\begin{tabular}{|c|c|}
\hline Title & 28. Social meetings \\
\hline Source & $\begin{array}{l}\text { - Senior learners } \\
\cdot \quad \text { Management }\end{array}$ \\
\hline Edu. dim. & - Activities \\
\hline QoL dim. & $\begin{array}{l}\text { - Social integration } \\
\text {. Personal fulfilment }\end{array}$ \\
\hline Justification & $\begin{array}{l}\text { Occasional social events (Easter, Christmas, New Year, etc.) are an } \\
\text { opportunity to make new contacts, friendships, exchange views and } \\
\text { strengthen a sense of belonging to a community, thereby increasing } \\
\text { socialisation. } \\
\text { These occasions should be designed as time for leisure, enjoyment } \\
\text { and spending time usefully, not as a social obligation, allowing se- } \\
\text { niors to enjoy themselves before, during and after the event. }\end{array}$ \\
\hline Requirements & $\begin{array}{l}\text { 1. Events are organised on special dates. } \\
\text { 2. Photographs are available to remind people of the events. }\end{array}$ \\
\hline 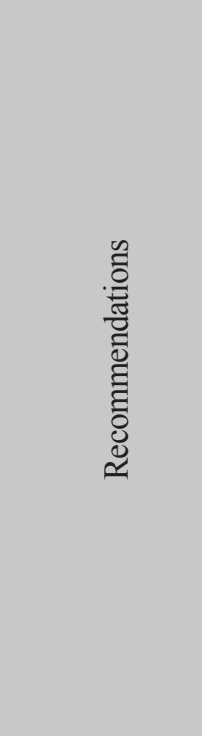 & $\begin{array}{l}\text { These events should be organised by the institution but the decision } \\
\text { on the place, time and cost to be incurred by participants should be } \\
\text { made in consultation with the seniors' representatives. } \\
\text { These events may be the only chance for some people who live alone } \\
\text { to celebrate particular holidays. Although the institution staff or class- } \\
\text { mates should not be considered as family or relatives, it is beneficial } \\
\text { to organise these events as part of a big family, thereby building new } \\
\text { relationships among senior citizens. } \\
\text { Events should be provided for leisure and pleasure, taking particular } \\
\text { account of people who are not used to joining in socially, or who feel } \\
\text { uncomfortable on these occasions and may find it difficult to join } \\
\text { in. If these events are organised by the institution, they can be more } \\
\text { inclusive and shy or introverted people may feel more inclined to } \\
\text { take part. } \\
\text { Displaying photos after the event helps people to re-live the expe- } \\
\text { rience once it has finished and recognise their participation in that } \\
\text { activity. }\end{array}$ \\
\hline
\end{tabular}




\begin{tabular}{|c|c|}
\hline Title & 29. Artistic performances \\
\hline Source & $\begin{array}{ll}\text {. } & \text { Senior learners } \\
\text {. } & \text { Management }\end{array}$ \\
\hline Edu. dim. & Activities \\
\hline QoL dim. & . Personal fulfilment \\
\hline Justification & $\begin{array}{l}\text { Group productions of artistic performances (e.g., theatre, choirs, } \\
\text { poetry) give great pleasure, and enable people to spend their free } \\
\text { time productively and creatively. They also develop sensitivity in } \\
\text { participants and their friends and family. } \\
\text { Coordinating, rehearsing and acting out a performance is a com- } \\
\text { plex process, and impacts on seniors by developing organisational } \\
\text { skills and responsibility. It also has an impact on their personal } \\
\text { growth by developing memory, creativity, providing rich aesthetic } \\
\text { experiences, educating the senses, imagination, intellect, experi- } \\
\text { encing a variety of moods and emotions, and overcoming shyness. } \\
\text { It provides a space to shed inhibitions, to build self-confidence and } \\
\text { self-esteem, to promote a sense of responsibility -both personal } \\
\text { and in the group- and to acquire freedom and openness in dealing } \\
\text { with people. }\end{array}$ \\
\hline Requirements & $\begin{array}{l}\text { 1. At least one arts activity is offered to all learners } \\
\text { 2. This activity (choir or theatre productions etc) is run at least twice } \\
\text { a year and is open to the public. }\end{array}$ \\
\hline 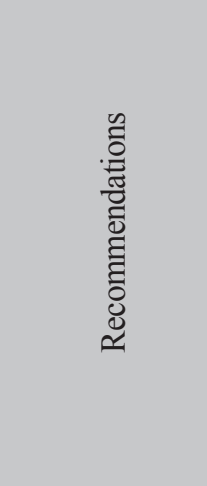 & $\begin{array}{l}\text { Depending on their competences and preferences, senior learners } \\
\text { can take on different responsibilities (actors, director, sound, ward- } \\
\text { robe, etc.). } \\
\text { The institution can promote this activity by sponsoring it, but } \\
\text { learners gain more from committing to the activity, and organising } \\
\text { it amongst themselves. } \\
\text { The impact of this activity is greater when it is put on for the pub- } \\
\text { lic, when it can be seen by their classmates and families. } \\
\text { The event should be free, unless it is decided to use the event as a } \\
\text { fund-raising opportunity for an NGO, which would also enhance } \\
\text { senior learners' standing in the community. }\end{array}$ \\
\hline
\end{tabular}




\begin{tabular}{|c|c|}
\hline Title & 30. Volunteering as a social contribution \\
\hline Source & $\begin{array}{l}\text { Senior learners } \\
\text { Management }\end{array}$ \\
\hline Edu. dim. & Activities \\
\hline QoL dim. & $\begin{array}{l}\text { Increase participation } \\
\text { Personal fulfilment }\end{array}$ \\
\hline 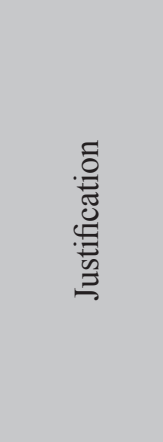 & $\begin{array}{l}\text { Senior citizens may have free time due to retirement or fewer family } \\
\text { commitments or duties. Most of them have gained a wealth of know- } \\
\text { ledge and expertise in some areas through their life experiences. All this } \\
\text { expertise should be passed on and can be used productively. } \\
\text { Promoting voluntary work can be beneficial from three perspectives: } \\
\text { firstly, senior learners' sense of usefulness and self-esteem increases, } \\
\text { and at the same time, it dispels any feelings of isolation. Secondly, other } \\
\text { people can benefit from their free time and experience, thus increasing } \\
\text { seniors' contribution to society. Finally, it creates a positive image of the } \\
\text { elderly in society. }\end{array}$ \\
\hline 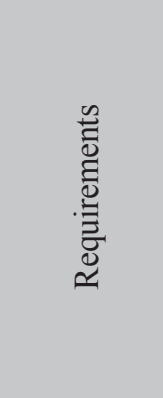 & $\begin{array}{l}\text { 1. The institution encourages learners to participate in voluntary activities } \\
\text { in the educational institution by helping or attending workshops, events, } \\
\text { activities, etc. (differentiating clearly from homework or activities that } \\
\text { form part of a course or subject). } \\
\text { 2. The institution encourages learners to participate in volunteer activities } \\
\text { outside the educational institution by presenting at least one external } \\
\text { voluntary activity. } \\
\text { 3. There is at least one group of senior learners involved in voluntary work } \\
\text { in the community or in another associated institution on a regular basis. }\end{array}$ \\
\hline 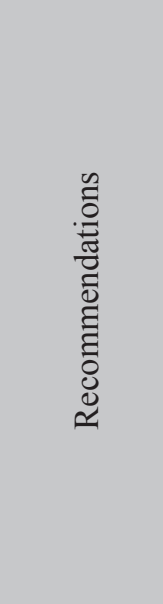 & $\begin{array}{l}\text { Although the voluntary activity can be done in the educational institu- } \\
\text { tion itself, by helping in the educational process (tutoring, helping to } \\
\text { organise activities, conferences, events, etc.), it has significant benefits } \\
\text { when it is done outside the institution, organised by an NGO or other as- } \\
\text { sociation. If it is done within the institution, it must be clearly differenti- } \\
\text { ated from educational activities; it must be productive and differentiated } \\
\text { work that has an impact on other people. } \\
\text { These activities should be planned and offered on the basis of the ex- } \\
\text { pertise and needs of the volunteers; contact people running third sector } \\
\text { (NGOs, or associations) projects and invite them to meet seniors to ex- } \\
\text { plain the advantages of volunteering and motivate them to action. } \\
\text { Keep a record of people who have undertaken voluntary work and study } \\
\text { the changes and influence of seniors participating in volunteering. Dis- } \\
\text { seminate the results. }\end{array}$ \\
\hline
\end{tabular}




\begin{tabular}{|c|c|}
\hline Title & 31. Digital inclusion \\
\hline Source & $\begin{array}{l}\text { Senior learners } \\
\text {. } \\
\text { Management }\end{array}$ \\
\hline Edu. dim. & - Activities \\
\hline QoL dim. & $\begin{array}{ll}\cdot & \text { Social integration } \\
\cdot & \text { Participation } \\
\cdot & \text { Perceived control } \\
\cdot & \text { Personal growth } \\
\text {. } & \text { Personal fulfilment }\end{array}$ \\
\hline 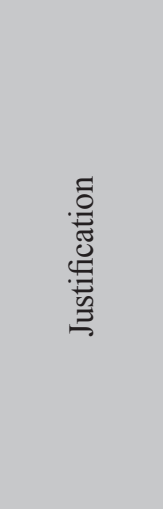 & $\begin{array}{l}\text { Society is changing, and technology is increasing used in everyday pro- } \\
\text { cesses in communities: family, friends, classmates, institutions; and in new } \\
\text { scenarios: services, learning, government, media and power. } \\
\text { Senior citizens should not only be able to use technology, but also feel part } \\
\text { of the technological society (digital inclusion) where they belong, have an } \\
\text { identity, can participate or collaborate, and can use the net not just to access } \\
\text { information, but to learn and help build it through their positive criticism. } \\
\text { Virtual social groups formed in virtual communities or by links among peo- } \\
\text { ple with common interests can be a useful way of obtaining more informa- } \\
\text { tion, enjoyment and support. } \\
\text { Sometimes, because they live in rural areas or due to disability, ICT can be } \\
\text { the most important way for seniors to integrate in society. }\end{array}$ \\
\hline 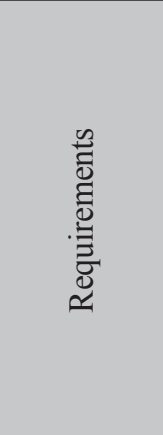 & $\begin{array}{l}\text { 1. Senior learners have an identity on the net and use it regularly (e.g., they } \\
\text { have an email account or accounts in forums or virtual networks). The senior } \\
\text { learner is aware of him/herself on the net, able to share and contact other net- } \\
\text { colleagues (eager to use technology, has a positive experience). } \\
\text { 2. The institution provides a public web platform where learners can collabo- } \\
\text { rate (write or upload photos or videos) be creative and share. } \\
\text { 3. The institution has a virtual social network that learners can join. } \\
\text { 4. The number of students that join this virtual network and use other tools } \\
\text { promoted by the institution is much higher than the average use of ICT tools } \\
\text { in the general population above } 65 \text {. }\end{array}$ \\
\hline 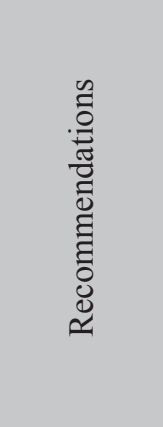 & $\begin{array}{l}\text { Provide a technological platform (website) and communication tools (email) } \\
\text { and promote their use among learners by sending regular mails, updating } \\
\text { photos, materials, general information, etc. } \\
\text { - Use ICT classes as an unthreatening environment where students can learn } \\
\text { and try out new services and applications. } \\
\text { Promote useful ICT use, increasing e-adoption (use) but also the experi- } \\
\text { ence (joy, pleasure, recreation). Increase self-confidence through training, } \\
\text { increase security through knowledge and create new spaces by allowing cre- } \\
\text { ativity and freedom of expression through social platforms for publication } \\
\text { (web } 2.0 \text { tools). }\end{array}$ \\
\hline
\end{tabular}




\begin{tabular}{|c|c|}
\hline Title & 32. Expertise exchange \\
\hline Source & $\begin{array}{ll} & \text { Management, internal regulations } \\
\text {. } & \text { Trainers } \\
\text {. } & \text { Senior learners }\end{array}$ \\
\hline Edu. dim. & $\begin{array}{l}\text { Activities } \\
\text { Courses }\end{array}$ \\
\hline QoL dim. & $\begin{array}{l}\text { Psychological health } \\
\text {. Control }\end{array}$ \\
\hline :气 & $\begin{array}{l}\text { Senior citizens have a lot of experience, and their knowledge can be } \\
\text { useful to other learners. These experiences can be related to any social } \\
\text { or family experience that has affected them in the past and that can be } \\
\text { transferred to another person with similar problems. } \\
\text { Issues that can be transferred should not be private or sensitive; this } \\
\text { would not easily occur among learners who do not know each other } \\
\text { or who have low levels of confidence. It can occur around everyday } \\
\text { issues such as peer tutoring on ICT, languages or other subjects or } \\
\text { activities. This first step can be promoted and monitored by the institu- } \\
\text { tion, while the second step (where support networks and exchange of } \\
\text { experience are transferred) occurs informally over time. }\end{array}$ \\
\hline 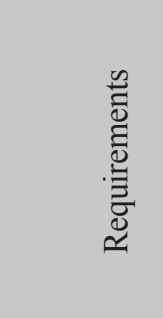 & $\begin{array}{l}\text { 1. The institution offers senior learners the chance to participate in bilat- } \\
\text { eral meetings (peer-to-peer or small groups). This activity lasts long } \\
\text { enough (over an academic year) to facilitate the creation of support } \\
\text { links, and the exchange of experience and expertise among learners. } \\
\text { 2. Learners have supportive classmates: learners with different expertise } \\
\text { meet and share spaces (real or virtual) to continue learning and social- } \\
\text { ising but also to lend support. }\end{array}$ \\
\hline 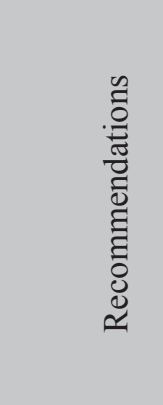 & $\begin{array}{l}\text { Offer and promote peer tutoring among learners by creating a list of } \\
\text { topic-based groups that learners can join. } \\
\text { For this activity to be lasting, experience transfer should be two-way, } \\
\text { otherwise, one party may soon lose interest. } \\
\text { Organise exhibitions of best practices, or compile a 'team book' with } \\
\text { collected knowledge, practices, etc. } \\
\text { Plan a course or activity where learners form groups to work on a } \\
\text { specific topic. This relationship should last throughout the whole aca- } \\
\text { demic course, thus encouraging the creation of links among learners. }\end{array}$ \\
\hline
\end{tabular}




\begin{tabular}{|c|c|}
\hline Title & 33. Artistic creativity \\
\hline Source & $\begin{array}{l}\text { Management, internal regulations } \\
\text { Senior learners }\end{array}$ \\
\hline Edu. dim. & $\begin{array}{l}\cdot \text { Activities } \\
\cdot \text { Courses }\end{array}$ \\
\hline QoL dim. & $\begin{array}{l}\text { Psychological health } \\
\cdot \text { Personal growth } \\
\text { Personal fulfilment }\end{array}$ \\
\hline Justification & $\begin{array}{l}\text { Creating something artistic (photography, stories, handicrafts, paint- } \\
\text { ing, etc) can be seen as a way of spending time productively to do a } \\
\text { specific task, or one requiring mental and physical efforts, but also as } \\
\text { a form of expression and a way to gain recognition from colleagues, } \\
\text { family and friends. } \\
\text { In some courses or activities where the theoretical concepts are par- } \\
\text { ticularly exacting, practical learning may be encouraged by creative- } \\
\text { ly sharing the concepts learnt. } \\
\text { Selecting the right methods for working with seniors affects the way } \\
\text { content is received and results in a greater willingness to participate } \\
\text { in the class, more confidence, commitment and assertiveness. }\end{array}$ \\
\hline Requirements & $\begin{array}{l}\text { 1. At least one activity offers a space for learners to be creative and } \\
\text { express themselves. } \\
\text { 2. Final work is presented or displayed to the rest of the community us- } \\
\text { ing media such as whiteboards, display cabinets, website). }\end{array}$ \\
\hline 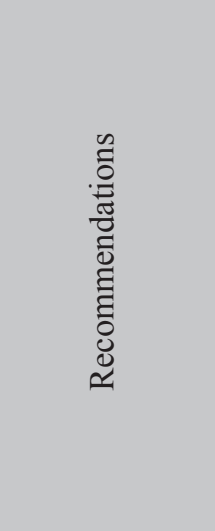 & $\begin{array}{l}\text { Offer artistic and creative activities that can be combined with other } \\
\text { courses. This will increase interest in the subject being taught, and at } \\
\text { the same time, will impact on the individual. } \\
\text { For example, use of ICT and technologies like cameras may also } \\
\text { include a photography contest. Language and writing courses can } \\
\text { include poetry or short story contests or publication of materials in } \\
\text { a local magazine or website. History of arts courses can be comple- } \\
\text { mented by painting workshops. } \\
\text { Artistic creations such as handicrafts or ceramics can be displayed in } \\
\text { exhibitions for the rest of the learners to see, thus increasing impact. } \\
\text { Activities should be conducted in small groups by themes, adapting } \\
\text { the offer to the seniors' hobbies and interests. }\end{array}$ \\
\hline
\end{tabular}




\subsection{STAFF AND TRAINERS}

The "Staff and Trainers" dimension includes the operational level of the personnel - coordinators, teachers, tutors, facilitators, administrative staff, etc.

- competences and skills

- functions and responsibilities

\begin{tabular}{|c|c|}
\hline Title & 34. Gerontology training \\
\hline Source & $\begin{array}{l}\text { Manager, internal regulation } \\
\text {. } \\
\text { Course programme, pedagogical/gerontological guide }\end{array}$ \\
\hline Edu. dim. & - Trainers \\
\hline QoL dim. & - Indirect transfer \\
\hline Justification & $\begin{array}{l}\text { Trainers who teach senior learners should be aware of how they } \\
\text { differ from other kinds of students (e.g., younger people or adults), } \\
\text { and the differences in their learning processes and pedagogies. They } \\
\text { should also be aware of their general needs and risks, and of how to } \\
\text { address their specific needs in the right way. This will allow trainers } \\
\text { to meet learners' needs and design more effective courses. } \\
\text { Elderly people are often still seen as one uniform group despite the } \\
\text { fact that seniors are more heterogeneous than the middle-aged (in } \\
\text { terms of variety in age, functional capacity, educational background } \\
\text { and life history). Educational activities must be tailored to their needs } \\
\text { and trainers should have the skills to deal with these challenges. } \\
\text { The problem of ageism has many consequences. Trainers should } \\
\text { have a thorough understanding of ageing so as to avoid stereotypes } \\
\text { or models. They should respect seniors as individual people, each } \\
\text { with their own unique background. } \\
\text { Research shows that people can learn up to great ages. Learning new } \\
\text { skills and cognitive processing take more time. Similarly, move- } \\
\text { ments are usually slower than in younger people. All these aspects } \\
\text { should be considered in pedagogical applications. }\end{array}$ \\
\hline Requirements & $\begin{array}{l}\text { 1. There is a training course or guide to inform new trainers about ge- } \\
\text { rontological concepts and pedagogical recommendations. } \\
\text { 2. There is a procedure where a trainer can get professional advice } \\
\text { about ageing-related issues or the pedagogical challenges of teach- } \\
\text { ing older learners. }\end{array}$ \\
\hline
\end{tabular}




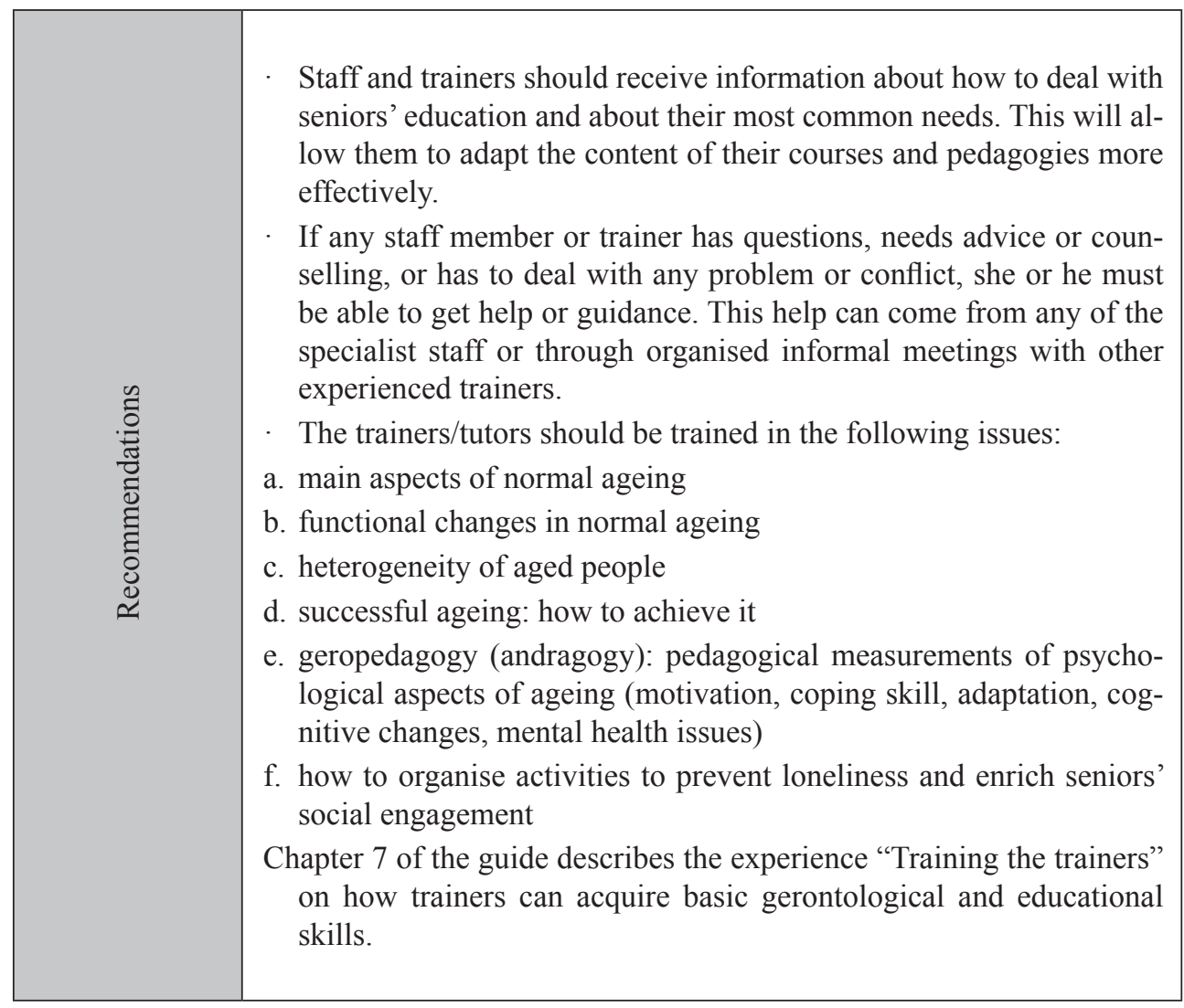

\begin{tabular}{|l|l|}
\hline Title & 35. Intercultural awareness, diversity and multiculturalism \\
\hline Source & $\begin{array}{l}\cdot \text { Manager, internal regulation } \\
\cdot \text { Trainers and staff } \\
\cdot \text { Senior learners }\end{array}$ \\
\hline Edu. dim. & $\begin{array}{l}\cdot \text { Staff, trainers } \\
\cdot \text { Courses }\end{array}$ \\
\hline QoL dim. & $\begin{array}{l}\text { - Social integration } \\
\text { Participation }\end{array}$ \\
\hline
\end{tabular}




\begin{tabular}{|c|c|}
\hline Title & 35. Intercultural awareness, diversity and multiculturalism \\
\hline Justification & $\begin{array}{l}\text { Increased intercultural awareness, diversity and multiculturalism in a } \\
\text { changing world, where people of different ethnicity, race, religion, cul- } \\
\text { tural and linguistic backgrounds live together, is one of the key social } \\
\text { skills in modern society. } \\
\text { There is a recognised need for people within a community, especially } \\
\text { regions with mixed populations, to adapt to the changes, to be more } \\
\text { tolerant of new cultures, to understand and recognise differences. Such } \\
\text { knowledge and skills are vital for ethnic and religious tolerance within } \\
\text { a society, and for positive interaction and co-existence among groups. } \\
\text { Although it is possible to teach tolerance and diversity through courses } \\
\text { on history and philosophy, trainers must have the skills to deal with dif- } \\
\text { ferent cultural groups or possible discrimination in class (due to social } \\
\text { class, gender or any other difference). }\end{array}$ \\
\hline 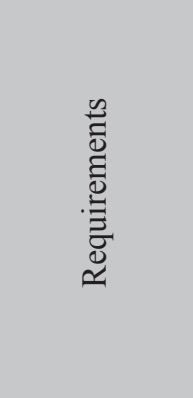 & $\begin{array}{l}\text { 1. Intercultural awareness, diversity and multiculturalism are part of the in- } \\
\text { stitution's mission statement, or are written into its educational policy. } \\
\text { 2. All new staff and trainers attend a training programme or receive ade- } \\
\text { quate information on intercultural awareness, diversity and multicultur- } \\
\text { alism issues, how to deal with social, gender or any other discrimination } \\
\text { in class and how to avoid it and promote equality. } \\
\text { 3. Learners feel that they have a better intercultural awareness, knowledge } \\
\text { of other cultures and customs, they are more tolerant, and they can rec- } \\
\text { ognise and acknowledge diversity and multiculturalism. }\end{array}$ \\
\hline 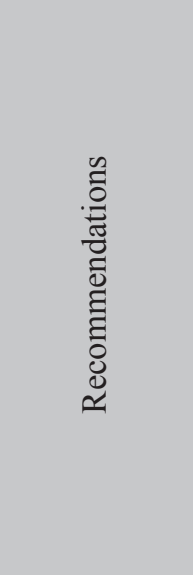 & $\begin{array}{l}\text { Provide intercultural and multicultural training for trainers on how to } \\
\text { deal with social differences, ethnic or gender prejudices in class. } \\
\text { Teach skills and aptitudes for tolerance, critical and constructive atti- } \\
\text { tudes, learning to learn and how to adapt to changes. } \\
\text { Base training on learners' own experiences and needs in this area. Focus } \\
\text { on the established need for religious, ethnic, cultural and linguistic toler- } \\
\text { ance. Point out the mutual benefits from interaction between different } \\
\text { cultures. } \\
\text { Provide learners with rationale, justification and proof of why knowing } \\
\text { how to communicate with different cultures will improve their interper- } \\
\text { sonal and communication skills. } \\
\text { Offer learners practical information and case studies with discussion top- } \\
\text { ics. }\end{array}$ \\
\hline
\end{tabular}




\begin{tabular}{|c|c|}
\hline Title & 36. Trainers communication skills \\
\hline Source & $\begin{array}{ll} & \text { Trainers, facilitators } \\
\cdot & \text { Managers } \\
\cdot & \text { Evaluation forms and results }\end{array}$ \\
\hline Edu. dim. & Staff, trainers \\
\hline QoL dim. & . Indirect transfer \\
\hline Justification & $\begin{array}{l}\text { Trainers' communication skills are essential to maintaining high } \\
\text { levels of attention and motivation among learners. } \\
\text {. The content taught and the information provided in the course is } \\
\text { very important, but the passion that the trainer transmits can some- } \\
\text { times be far more important, as it stimulates learners' interest. } \\
\text { Communication is an essential skill in a trainer, not only to pass on } \\
\text { knowledge on a course but also to transmit other skills and social } \\
\text { attitudes, particularly during discussion, debates, or direct interac- } \\
\text { tion with learners. }\end{array}$ \\
\hline Requirements & $\begin{array}{l}\text { 1. There is an evaluation procedure (formal or informal, such as in- } \\
\text { terviews) to ensure that new trainers have not only the necessary } \\
\text { knowledge about the topic but also the right communication skills. } \\
\text { 2. There are methods to evaluate trainers' communication and asser- } \\
\text { tion skills (such as learners' evaluation of trainers' competences). } \\
\text { 3. Managers take corrective action when it a trainer does not have suf- } \\
\text { ficient communication skills. }\end{array}$ \\
\hline 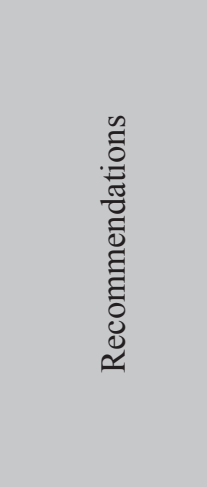 & $\begin{array}{l}\text { Capacity to communicate and deal with a group of learners is a key } \\
\text { competence for trainers of seniors. Without that competence, the } \\
\text { teaching-learning process will probably end in failure. New trainers } \\
\text { should have sufficient knowledge and communication skills; if not, } \\
\text { they should not be employed. } \\
\text { - Questionnaires should be given to learners to evaluate the trainers' } \\
\text { competences and communication skills. } \\
\text { - Provide regular workshops for trainers about how to enhance com- } \\
\text { munication skills. } \\
\text { Organise workshops where more experienced trainers can exchange } \\
\text { recommendations and advice. }\end{array}$ \\
\hline
\end{tabular}




\begin{tabular}{|c|c|}
\hline Title & 37. Professional burnout and stress management \\
\hline Source & $\begin{array}{l}\text { Trainers, facilitators, tutors, general staff } \\
\text { Management, internal regulation }\end{array}$ \\
\hline Edu. dim. & Staff, trainers \\
\hline QoL dim. & Indirect transfer \\
\hline Justification & $\begin{array}{l}\text { Senior learners can be very active; they can be demanding not only dur- } \\
\text { ing, but also before and after class. For the specialists or general staff } \\
\text { working in the department and helping seniors, such a demanding public } \\
\text { can be difficult to deal with. All this continuous work can be exhausting } \\
\text { and can cause burnout that eventually leads to deterioration in the quality } \\
\text { and sensitivity of the work done by trainers and staff. } \\
\text { Trainers and staff, because of their daily work, or the way the courses } \\
\text { are planned, may have doubts or questions about evaluation methods, } \\
\text { preparing activities, publishing materials, organising events, etc. } \\
\text { Because the elderly are so heterogeneous (compared with young adults } \\
\text { who are more passive, as their main motivation is to get their degree), } \\
\text { it is not easy to meet everybody's needs and accommodate everybody's } \\
\text { tastes. This can give rise to complaints; less frequently, some seniors can } \\
\text { be very insistent. } \\
\text {. Trainers and staff should have channels to receive coaching and advice } \\
\text { from other more experienced colleagues, or at least support from the } \\
\text { management. This not only increases the quality of the educational activ- } \\
\text { ity but also reduces their stress levels. }\end{array}$ \\
\hline 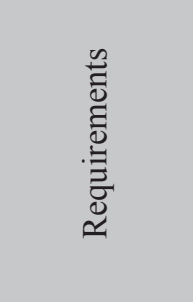 & $\begin{array}{l}\text { 1. The details of the courses and activities are designed by the trainer, but } \\
\text { there is also a well-established channel (e.g., revision by a specialist, ap- } \\
\text { proval from the management) for trainers to seek improvement and ad- } \\
\text { vice about their courses and activities, particularly for new trainers. } \\
\text { 2. There is a well-established channel (regular meetings, workshops, spe- } \\
\text { cialists) for trainers or staff to receive support and advice about their } \\
\text { daily work problems, conflicts or doubts. }\end{array}$ \\
\hline 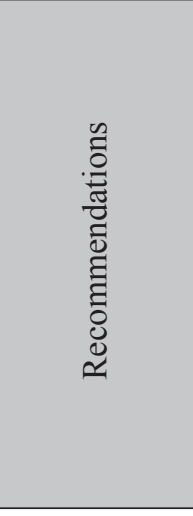 & $\begin{array}{l}\text { There should be a channel for the most experience trainers and staff to } \\
\text { transmit best practises for dealing with daily work. This not only in- } \\
\text { creases the quality of the staff, but also makes working a more pleasant } \\
\text { experience. } \\
\text { - A gerontologist or psychologist can provide support and advice to other } \\
\text { trainers and staff about how to deal with stressful situations. } \\
\text { When designing educational activities, trainers must be aware of seniors' } \\
\text { requirements and needs, but also try to avoid techniques or pedagogies } \\
\text { that would result in failure because of factors specific to the seniors' con- } \\
\text { text. New trainers should show their course programme to a specialist or } \\
\text { trainer with experience, so they can give advice and support in difficult } \\
\text { situations. }\end{array}$ \\
\hline
\end{tabular}




\begin{tabular}{|c|c|}
\hline Title & 38. Motivation and optimism \\
\hline Source & Senior learners \\
\hline Edu. dim. & $\begin{array}{l}\text { Staff and trainers } \\
\text { Pedagogy }\end{array}$ \\
\hline QoL dim. & $\begin{array}{l}\cdot \text { Control } \\
\cdot \text { Psychological health } \\
\cdot \text { Personal growth } \\
\cdot \text { Personal fulfilment }\end{array}$ \\
\hline Justification & $\begin{array}{l}\text { Optimism is an attitude to life that can be learnt, but only } \\
\text { if a trainer truly believes in it. Optimism is the tendency to } \\
\text { perceive and evaluate the world constructively, attempting } \\
\text { to avoid negative unproductive beliefs, but taking a realistic } \\
\text { and useful positive view that helps solve the problems we } \\
\text { all face. } \\
\text { Optimism inspires individuals to believe that they will reach } \\
\text { the goals they set themselves, and helps them to make deci- } \\
\text { sions about how to do so. When difficulty is encountered, } \\
\text { optimism encourages people to continue in their efforts. It } \\
\text { also protects against situations that are beyond an individu- } \\
\text { al's control. } \\
\text { Constructive criticism should be encouraged during teach- } \\
\text { ing, as opposed to destructive criticism, which only uncovers } \\
\text { negative or bad aspects of everyday life, and does not pursue } \\
\text { solutions. } \\
\text { Trainers must be aware that teaching seniors is not about } \\
\text { increasing their professional skills or working towards a de- } \\
\text { gree, but increasing the life skills needed to deal with chal- } \\
\text { lenges and factors beyond their control. Therefore, teaching } \\
\text { must be oriented to real, daily life problems where senior } \\
\text { learners can change their destructive habits into constructive } \\
\text { behaviours. }\end{array}$ \\
\hline 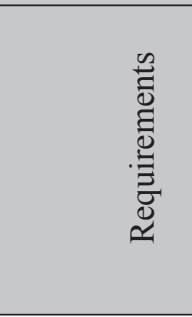 & $\begin{array}{l}\text { 1. Senior learners consider that trainers use a positive and cons- } \\
\text { tructive approach to transmit the course content. They affirm } \\
\text { that their perception of problems or situations beyond their } \\
\text { control has changed for the better since attending class. } \\
\text { 2. Senior learners feel motivated to face new challenges in } \\
\text { life and claim that this feeling has increased since attending } \\
\text { class. }\end{array}$ \\
\hline
\end{tabular}


- The trainer must have the attitudes and the persuasive capacity to create a sense of security in the classroom, allowing seniors to shape attitudes of trust in the world and in others, and to strengthen their faith in their ability to deal with difficult and stressful situations.

- The trainer should positively motivate seniors at every stage in the course or class activity and in meeting other challenges outside the classroom. Trainers should regularly remind learners what the aims of the course and the lesson are, and reinforce learners' awareness of what they have achieved.

- Although trainers should transmit motivation and optimism to learners on all courses, there are some subjects that can provide learners with the tools to deal with difficult situations. These are mainly humanities-based subjects (psychology, sociology, philosophy, history). Trainers should also provide examples and cases for discussion, and attempt to show that solving and controlling situations from a positive and constructive perspective is better for ourselves and for those around us.

- Learners become more motivated and feel more in control once the course or activity has finished and they realise how many skills and attitudes they have acquired. It is the trainer's responsibility to bring this progress to their attention. 


\section{ANNEX I}

\begin{tabular}{|l|l|}
\hline \multicolumn{2}{|c|}{ EVALUATION FORM } \\
\hline Institution & \\
\hline Name of evaluator & \\
\hline Date & \\
\hline
\end{tabular}

Score:

\begin{tabular}{|c|c|c|}
\hline 0 - No evidence & $\begin{array}{l}\text { Fails to include a minimum amount } \\
\text { of evidence to enable evaluation of } \\
\text { the indicator }\end{array}$ & $\begin{array}{l}\text { Weaknesses: } \\
\text { a. Evidence failures }\end{array}$ \\
\hline 1 - Very weak & $\begin{array}{l}\text { Meets the indicator's requirements } \\
\text { but with significant or many weak- } \\
\text { nesses }\end{array}$ & $\begin{array}{ll}\text { b. } & \text { Design failures } \\
\text { c. } & \text { Low impact } \\
\text { d. } & \text { Other (detail) }\end{array}$ \\
\hline 2 - Weak & $\begin{array}{l}\text { Meets the indicator's requirements } \\
\text { but with some weaknesses }\end{array}$ & \\
\hline 3 - Acceptable & $\begin{array}{l}\text { Meets the indicator's requirements } \\
\text { satisfactorily (threshold) }\end{array}$ & Threshold \\
\hline 4 - Good & $\begin{array}{l}\text { Meets the indicator's requirements } \\
\text { with some high quality aspects }\end{array}$ & $\begin{array}{l}\text { Quality factors: } \\
\text { A. Well-established }\end{array}$ \\
\hline 5 - Very good & $\begin{array}{l}\text { Meets the indicator's requirements, } \\
\text { all aspects of high quality }\end{array}$ & $\begin{array}{l}\text { B. Continuous improve- } \\
\text { ment } \\
\text { C. Indirect transfer } \\
\text { D. Exchange } \\
\text { E. Other (detail) }\end{array}$ \\
\hline
\end{tabular}

Decimal scores are admitted 


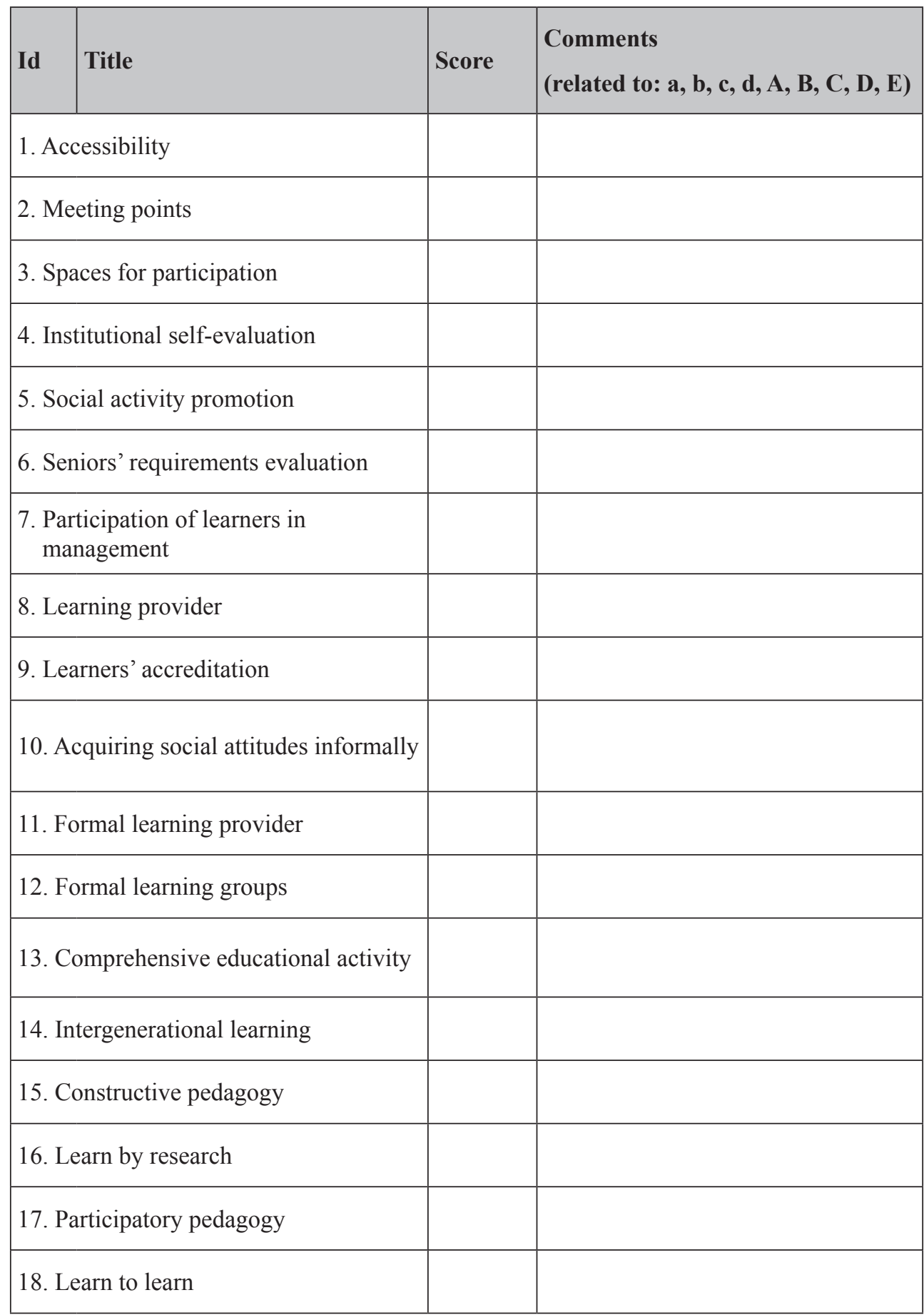




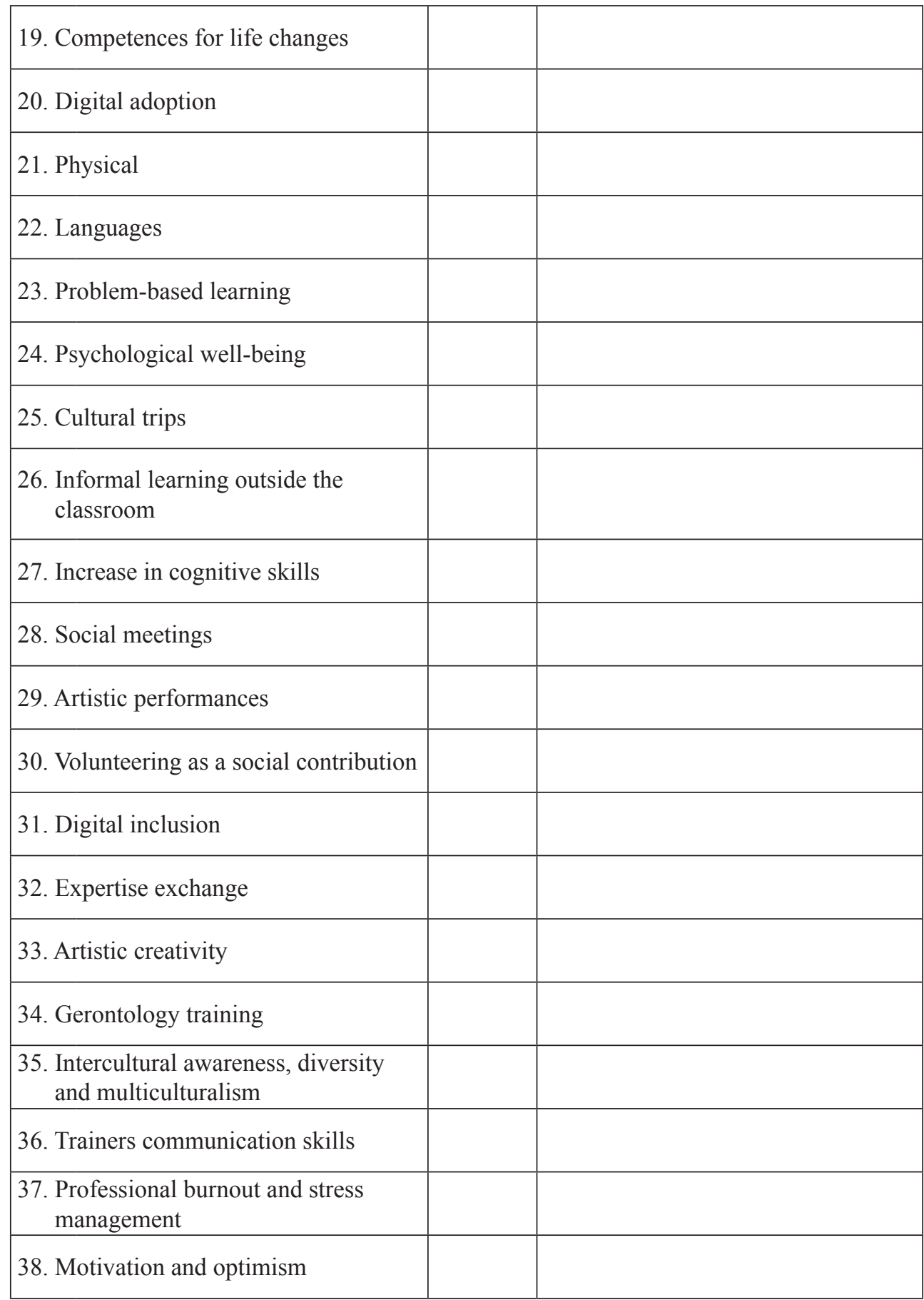

Final score:

Average: 
Evaluation toolkit for educational institutions

Comments:

Include here any comments on or justifications for scores in the above indicators.

This form can be also downloaded from http://www.edusenior.eu 


\section{ANNEX II}

\begin{tabular}{|l|l|}
\hline \multicolumn{2}{|c|}{ REPORT } \\
\hline Institution & \\
\hline Name of evaluator & \\
\hline Date & \\
\hline
\end{tabular}

Below you will find four fields (boxes) with information you should complete under the headings Strengths, Threats, Weaknesses and Opportunities. In the header of each box, help is given about the questions that should be answered in the box. There is an extra box for your comments and suggestions. All this information, together with the score, will constitute the report to be delivered to the management.

The content for completing these boxes is that from the Annex I (with each indicator and its score). The justification of each indicator and its recommendations should also be borne in mind.

\section{Strengths}

Concerning indicators that are evaluated with a high score;

- What are the most relevant dimensions (institutional and QoL) in which the institution stands out? (area of expertise)

- How can its impact be shared with the community or with other institutions, decision makers or in other networks? (sharing and exchange, creating synergies) 


\section{Threats}

Concerning indicators that are evaluated with a high score

- How can their medium or long-term impact be improved or ensured? (quality assurance)

- For indicators that are at risk of worsening in the medium or long term, what corrective actions should be taken and recommendations followed? (risk management)

\section{Weaknesses}

Concerning indicators that are evaluated with a low score, and that are part of the strategic and operational aims of the institution,

What corrective actions can be taken? (recommendations) 


\begin{tabular}{l}
\hline Opportunities \\
Concerning indicators that are evaluated with a low score, and that are NOT part of the \\
strategic and operational aims of the institution: \\
Based on the potentialities of the institution (educational dimensions, staff exper- \\
tise, experience, operational capacity, etc.) and also on the environment (social \\
context of the elderly, network with other institutions, associations, etc.): What \\
new actions can be recommended (new courses, new processes, new activities, \\
etc.) and taken into consideration to impact on learners' QoL (potentialities)? \\
\hline
\end{tabular}

\section{Recommendations / Comments}

Include here any recommendations or comments that do not fall within the previous categories. These may include the following areas, but the list is not exhaustive:

- Cultural and institution target-specific recommendations

- Further steps or recommended actions for continuous improvement; internal (mission, organisation, evaluation, research) or external (networks, associations, etc.)

- Risks or weaknesses not detailed by indicators that could affect the institutions and the seniors' QoL

This form can be also downloaded from http://www.edusenior.eu 
The target of the European project EduSenior is to improve the quality and effectiveness of educational institutions aimed at senior learners. Senior citizens (understood as retired people, usually $65+)$ have specific needs and risks, but also new opportunities and potential. Increased life expectancy and health mean seniors will be a significant population group in a future Europe. Education can help senior citizens better adapt to this constantly changing society and take greater control over their lives. Education can help them to be healthier, more independent and more integrated in their communities while participating actively and being creative; in sum, enjoying a more valuable life. These aims are all framed in the concept of quality of life. The EduSenior project firmly believes in the significant role of educational institutions to increase senior citizens' quality of life, which is positive for themselves but also for society in general.

This evaluation toolkit is the second of two main outcomes of EduSenior, the first being a pedagogical guide. Both products can be used by managers, staff, trainers, tutors, facilitators, decision-makers, researchers and anyone interested in seniors' education. The guide introduces the main concepts, including experiences in the European context. The evaluation toolkit is more practical, providing useful indicators for assessment, but also recommendations and ideas for the operational level. 

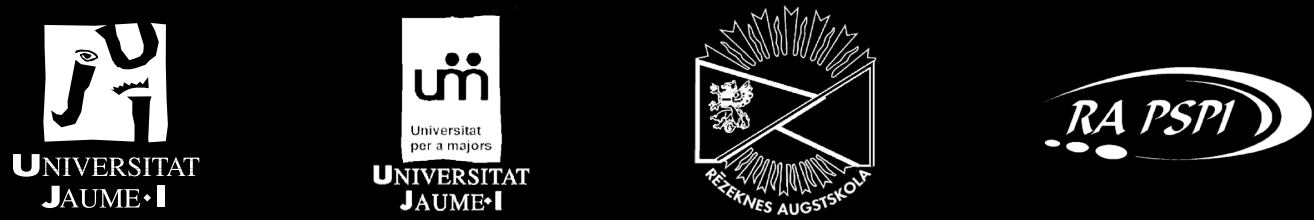